Santa Clara University

Scholar Commons

Accounting

Leavey School of Business

$3-2007$

\title{
Underwriter choice and earnings management: evidence from seasoned equity offerings
}

Hoje Jo

Yongtae Kim

Santa Clara University, y1kim@scu.edu

Myung Seok Park

Follow this and additional works at: http://scholarcommons.scu.edu/accounting

Part of the Accounting Commons

\section{Recommended Citation}

Jo, Hoje, Yongtae Kim, and Myung Seok Park. "Underwriter Choice and Earnings Management: Evidence from Seasoned Equity Offerings." Review of Accounting Studies 12.1 (2007): 23-59.

The final publication is available at Springer via http://dx.doi.org/10.1007/s11142-006-9019-7.

This Article is brought to you for free and open access by the Leavey School of Business at Scholar Commons. It has been accepted for inclusion in Accounting by an authorized administrator of Scholar Commons. For more information, please contact rscroggin@scu.edu. 


\title{
Underwriter choice and earnings management: evidence from seasoned equity offerings
}

HOJE JO

hjo@scu.edu

Leavey School of Business, Santa Clara University, 500 El Camino Real, Santa Clara, CA 95053, USA

YONGTAE KIM*

y1kim@scu.edu

Leavey School of Business, Santa Clara University, 500 El Camino Real, Santa Clara, CA 95053-0380,

USA

Tel.: +1-408-554-4667; fax: +1-408-554-5193

MYUNG SEOK PARK

mspark@vcu.edu

School of Business, Virginia Commonwealth University, 1015 Floyd Ave, Richmond, VA 23284, USA

\begin{abstract}
Using a sample of seasoned equity offerings (SEOs), this paper examines the association between the choice of financial intermediary and earnings management. We contend that with more stringent standards for certification and intense monitoring, highly prestigious underwriters restrict firms' incentives for earnings management to protect their reputation and to avoid potential litigation risks, while firms with greater incentives for earnings management avoid strict monitoring by choosing lowquality underwriters. Consistent with our predictions, we find an inverse association between underwriter quality and issuers' earnings management. In addition, we find that underwriter quality is positively related to SEOs' post-issue performance, even after controlling for the effect of earnings management. We also find that firms with low underwriter prestige and high levels of earnings management underperform the most. However, the effect of underwriter choice on post-issue performance does not last long.
\end{abstract}

Keywords: underwriter reputation, underwriter choice, earnings management, seasoned equity offerings, post-issue performance

JEL Classification: M41, G14, G24, G32

\footnotetext{
* Corresponding author
} 
Researchers examine various incentives for earnings management: contracting motivations, responding to anti-trust or other governmental regulations, and recently, capital market motivations. Positive accounting theory hypothesizes opportunistic earnings management and explains managers' accounting procedure choices (Watts and Zimmerman, 1978, 1986). ${ }^{1}$ Kothari (2001) argues that the motivation for earnings management research has expanded from contracting and political process considerations in an efficient market to include earnings management designed to influence stock prices. He reports that a recent, popular area of research examines the joint hypothesis of market inefficiency and earnings management with a capital market motivation, for example, an incentive to manipulate accruals upward during periods prior to stock issues (Dechow et al., 1996). Teoh et al. (1998a and 1998b) and Rangan (1998) show evidence of unexpected accruals around equity offerings and find that post-issue, long-run operating and return performances are negatively related to earnings management. They conclude that market participants fail to adjust for earnings management adequately. Others emphasize the penalties arising from false earnings signals (DuCharme et al., 2004).

While the impact of earnings management on the equity offering market has been studied extensively, the linkage between a firm's choice of a financial intermediary and earnings management remains unexplored. The central aim of this paper is to document the relation between a firm's choice of an underwriter in the event of a seasoned equity offering (SEO) and earnings management. ${ }^{2} \mathrm{We}$ also examine the impact of this relation on post-issue performance. ${ }^{3}$ We argue that a firm's decision regarding earnings management affects the choice of underwriters and vice versa, while the selection of underwriters is one of the most crucial factors leading to the success of equity offerings. Casual observation suggests that some firms prefer prestigious investment bankers and others choose the opposite. We maintain that firms that are more aggressive in their accounting decisions tend to use lower-quality underwriters to avoid intense monitoring because high-quality underwriters provide more stringent monitoring for better underwriter certification and to retain and accumulate their reputation capital. 
In general, underwriters are supposed to act as agents for the issuers' and investors' best interests. Less-prestigious underwriters, however, ignore their gate-keeping roles to keep profitable underwriting assignments. In contrast, high-quality underwriters are seriously concerned about earnings manipulation and therefore attempt to enhance the transparency of economic earnings. In fact, our conversation with U.S. Bancorp Piper Jaffray indicates that underwriters, in general, are disturbed by the possibility of earnings manipulation by the SEO firms they underwrite. An investment banker also suggests that due to underwriters' concern about earnings manipulation, high-quality underwriters usually hire high-quality auditors to prevent aggressive earnings management, which is consistent with Balvers et al. (1988), Elder and Zhou (2002), and Zhou and Elder (2004). ${ }^{4}$ Consequently, an inverse relation between earnings management and underwriter reputation is expected. ${ }^{5}$ We also anticipate that underwriter reputation protection, certification, and monitoring jointly mitigate agency conflicts and restrict earnings management, thereby reducing post-issue SEO underperformance.

Overall, empirical findings support our predictions. Using a sample of SEOs, we find that our earnings management proxy of unexpected total accruals is negatively associated with underwriter reputation. Within the simultaneous equations framework, we also find that underwriter reputation is negatively associated with unexpected total accruals. This inverse relation remains qualitatively unchanged with other proxies of earnings management, such as performance-adjusted discretionary total accruals, as suggested by Kothari et al. (2005). Different measurement windows of accruals do not change the results. An examination of the offerings that are subject to SEC enforcement actions confirms the inverse association between underwriter prestige and earnings management. These results suggest that the involvement of more prestigious underwriters reduces aggressive earnings management in the SEO setting. In turn, firms with aggressive (conservative) earnings management tend to avoid high- (low-) quality underwriters.

Our results also reveal that underwriter reputation is positively associated with post-issue return performance, even after controlling for the effect of earnings management and other confounding factors, implying that underwriter prestige reduces post-SEO underperformance. We further find that post-issue, 
operating performance is positively related to underwriter prestige and that the post-issue market penalizes firms with aggressive earnings management that hire low-quality underwriters. However, the impact of underwriter choice on post-issue performance does not last long, as the effect disappears after a year following the SEO's active earnings management period. We interpret the above results as indications that prestigious underwriters monitor the top management for offerings, thereby mitigating agency conflicts and overvaluation of the issues, and therefore reducing potential post-issue SEO underperformance. SEO overvaluation and post-issue underperformance may be explained by the behavioral model proposed by Daniel et al. (1998), which is based on investor overconfidence and on changes in confidence resulting from the biased self-attribution of investment outcomes. Their model shows that public information can trigger overreaction to a preceding private signal, and such continuing overreaction causes momentum in security prices; however, this momentum eventually is reversed as further public information gradually draws prices back toward fundamentals. Thus, according to their model, biased self-attribution implies short-term momentum (overvaluation) and long-term reversals (post-issue underperformance). ${ }^{6}$

Carter and Manaster (1990) examine the relation between underwriter quality and long-term IPO performance. McLaughlin et al. (2000) show that the market impounds the value of the underwriters' information and certification at the announcement of SEOs. However, these studies differ from ours in that they just examine the relation between underwriter quality and long-run market performance, without controlling potential earnings management effects. Recently, Chan et al. (2005) examine the impact of previously identified determinants (e.g., underwriter quality, earnings management, and venture capital backing) of long-run IPO performance. Our study highlights the effect of underwriter reputation on earnings management in SEOs, which differs from their focus on IPOs. Furthermore, while Chan et al. (2005) focus on long-term returns (four years), we examine various windows (from one to five years) of post-issue returns to show the lasting effects of both underwriter reputation and earnings management. We also examine operating performance in addition to stock returns. 
This paper contributes to the accounting and corporate finance literature in two ways. First, to the best of our knowledge, our paper is the first attempt to address the association between underwriter prestige and earnings management around SEOs. This study is important in light of recent controversies involving top-bracket investment banks in the late nineties, which disregarded ethics and gave more emphasis to the fees that they generated from their clients. Contrary to these assertions, our findings suggest that, in the years 1990-1997, more prestigious underwriters, in general, tend to restrict issuers' earnings management, and thereby sell the shares of firms with high earnings quality. Second, this paper addresses the relation between firms' behavioral choice of financial intermediaries and earnings management, and therefore it provides the existing literature with an additional dimension to the array of incentives associated with earnings management.

The remainder of the article is organized as follows. The next section examines the related literature and provides testable predictions. This is followed by a description of the data and measurement. In section 3, we present the empirical results on the relation between underwriter choice and earnings management by SEO firms. We summarize our analyses in the final section.

\section{Underwriter choice and earnings management}

\subsection{The endogenous determination of underwriter choice and earnings management}

To examine the relation between underwriter choice and earnings management, we consider their endogenous nature because issuers choose underwriters and their reporting strategies simultaneously. We expect that firms with greater incentives for earnings management will avoid high-quality underwriters, and the extent to which earnings are managed is likely to be lower for firms that select high-quality underwriters. This inverse relation between underwriter reputation and earnings management can be inferred from the literature on underwriter reputation, certification, and monitoring. ${ }^{7}$

First, high-prestige underwriters consider reputation capital important. Carter and Manaster (1990) and Chemmanur and Fulghieri (1994) suggest that underwriters, as repetitive players in the equity market, obtain and accumulate reputation capital. Underwriters gather information about an issuer's 
future prospects and evaluate whether the information is bias-free. If material information is not properly disclosed and the stock performs poorly, then investors can sue the underwriters. Different underwriters are likely to have different loss functions because high-reputation underwriters with deep pockets are subject to more litigation risks. Consequently, more prestigious underwriters have more to lose in terms of reputation and hence are more selective about the firms they pick.

Second, previous literature suggests that underwriters help reduce information asymmetry through certification in the United States (Booth and Smith, 1986; Beatty and Ritter, 1986; Chemmanur and Fulghieri, 1994; Ng and Smith, 1996; Puri, 1996; Dunbar, 2000; McLaughlin et al. 2000), the United Kingdom (Slovin et al. 2000), and Japan (Cooney et al. 2003). For instance, Booth and Smith (1986) argue that if the net benefit from revealing the true issuing-firm value of an SEO, after accounting for the cost of hiring a high-quality underwriter, exceeds the benefit of hiding the true issuing-firm value, then the firm will hire high-quality underwriters. Chemmanur and Fulghieri (1994) and McLaughlin et al. (2000) claim that high-quality underwriters can produce superior information about the firms they underwrite and have more stringent standards for certifying the issuing-firm's value. In summary, we expect issuers with minimal incentives for earnings management to select high-quality underwriters to enhance underwriter certification, thereby signaling favorable information to the marketplace. Furthermore, firms selecting prestigious underwriters are less likely to manage earnings because high-quality underwriters restrict issuers from managing earnings for better certification. This indicates a negative relation between underwriter reputation and earnings management.

Third, the negative relation between underwriter reputation and earnings management also can be inferred from the underwriters' monitoring function. More prestigious investment banks have more money and more expertise and are therefore likely to perform higher-quality due diligence (monitoring). Block and Hoff (1999) and Miller (2000) suggest that underwriters conduct due-diligence investigations to ensure full and fair disclosure to investors regarding the securities being offered, promote efficient and transparent markets, and prevent potential lawsuits. These due-diligence investigations include an analysis of the issuer's industry and discussions with the issuer's management to examine the completeness and accuracy of information regarding the issuer. The information includes, for example, 
the issuer's current financial health, the validity of the security offerings, and the issuer's future financial prospects, along with the independent auditors' analysis and opinions. Hansen and Torregrosa (1992) suggest that underwriter monitoring improves a firm's performance and reduces agency costs, thereby increasing firm value. They argue that if there is little monitoring in place, some issuers avoid strict monitoring by choosing low-quality underwriters. As a result, firms selecting high-quality underwriters are less likely to manage earnings, suggesting a negative relation between underwriter reputation and earnings management. Hence, we expect that

Prediction 1: Underwriter reputation is a decreasing function of earnings management, and vice versa.

\subsection{Underwriter choice, earnings management, and post-issue performance}

Prior literature reports the post-issue, long-run operating and stock market underperformance of SEO firms (Loughran and Ritter, 1995 \& 1997; Spiess and Affleck-Graves, 1995). We also have evidence of the effect of underwriter reputation on the post-issue performance of IPOs (Michaely and Shaw, 1994; Carter et al. 1998) and the effect of earnings management on the post-issue performance of SEOs (Teoh et al., 1998b). However, the effect of underwriter choice on SEOs' post-issue performance after controlling for earnings management is an empirical question that needs to be addressed, given the inverse relation between underwriter reputation and earnings management, as postulated in the previous section.

The economic role of underwriters is to reduce market frictions, such as "information asymmetries" and "agency problems," that otherwise increase the cost of capital. The role of underwriter reputation in reducing information asymmetries and mitigating the adverse selection faced by outside stockholders has been extensively studied in the context of IPOs. ${ }^{8}$ Even though SEO firms are not likely to suffer information asymmetries to the same extent as IPO firms, there are still information asymmetries regarding the expected future performance between the firms' insiders and potential investors in SEOs. In addition, prior literature reports that SEO firms in the 1990s faced greater uncertainty due to an increased proportion of riskier offerings, such as NASDAQ and technology issues in the 1990s (McLaughlin et al., 
2000; Corwin, 2003; Mola and Loughran, 2004). Based on this literature, we argue that there exists an information asymmetry between issuing firms and investors that can cause a temporal overvaluation of seasoned equity offers. A high-quality underwriter decreases information asymmetry by reducing the information gap between managers and investors through underwriter certification and intense monitoring, and inhibits short-term overvaluation, thereby reducing the potential underperformance of post-issue SEOs.

The positive effect of underwriter reputation on post-issue performance also can be postulated from the underwriter's role as a monitor of final offer pricing. Hansen and Torregrosa (1992) argue that the level of monitoring is related to the level of intrinsic value, so that there is a "schedule" of certifiable offer prices, depending on the level of monitoring. Following Hansen and Torregrosa (1992), we argue that high-quality underwriters perform better corporate monitoring and that reputable underwriters monitor issuers to reduce the possibility of severe underpricing or overpricing. ${ }^{9}$

If the certification and monitoring tasks are not performed adequately, the underwriter will damage its reputation. If an underwriter substantially misprices an issue, its reputation and future business are likely to be harmed. In addition, both the issuer and the investment bank can be sued. Consequently, we contend that underwriter reputation protection, certification, and monitoring together help decrease agency conflicts, possible SEO overvaluation, and therefore post-issue SEO underperformance. The implication that we draw from the above discussion leads to the following predictions.

Prediction 2. (a) The quality of the underwriter has a positive impact on the post-issue returns of SEO firms, even after the effect of earnings management is controlled; and (b) the post-issue returns of SEO firms with aggressive earnings management that select low-quality underwriters decline more than those of SEO firms with conservative earnings management that hire high-quality underwriters.

\section{Data and measurement}

We obtain an initial sample of 1,950 common stock SEOs that occurred between January 1990 and December 1997 from the Securities Data Corporation (SDC) database. We terminate our sample in 1997 to examine post-offering returns up to five years after the active earnings management period (i.e., up to 
2002). We limit the sample to U.S. firms available on the COMPUSTAT and Center for Research in Security Prices (CRSP) databases. Stock return data are obtained from the CRSP database and relevant financial variables are obtained from COMPUSTAT. Offerings by financial institutions are excluded because the nature of accruals for these firms is very different from that of industrial firms. We also exclude additional offerings filed less than two years after the initial public offerings to avoid the confounding effect of IPO performance.

Of the 1,950 offerings, we identify offering announcement dates for 1,489 offerings by searching press release wires in the Dow Jones Interactive (DJI) database system. We drop 63 offerings because the SEO was announced within two years of a spin-off or a merger creating the firm to avoid the effect of new firms. This process results in 1,426 offerings. The reputation score data of the lead underwriter are obtained from the updated list of the Carter-Manaster measure in Carter et al. (1998). ${ }^{10}$ We exclude 275 offerings because the underwriter reputation score data are not available and further eliminate 561 offerings due to insufficient data to calculate unexpected accruals, our measure of the empirical proxy for earnings management. Thus our final sample consists of 590 offerings. Actual samples used in the analyses are slightly different because the data availability varies for each regression analysis.

Table 1 reports the sample statistics and data characteristics of 590 offerings. Panel A provides summary information on size and offering characteristics. The mean and median of the total book value of equity are $\$ 320$ million and $\$ 79$ million, respectively. The mean and median of the market capitalization of equity are $\$ 958$ million and $\$ 264$ million, respectively. The size of the issuers ranges considerably in the sample, as indicated by the large standard deviations. The mean and median proceeds from the offerings are $\$ 96$ million and $\$ 54$ million, respectively. The mean increase in shares due to the offering is $24 \%$. Panel B illustrates that seasoned equity issues are not clustered by time periods. Panel C indicates that seasoned equity issues are clustered by industries. For instance, chemical products and computer industries comprise more than $22 \%$ of the sample. 
We report the results with the unexpected total accruals suggested by Hribar and Collins (2002) as our proxy for earnings management. We discuss the results with an alternative proxy for earnings management in a later section. Hribar and Collins (2002) argue that studies using balance sheet data to calculate accruals are potentially contaminated in testing for earnings management. Following Hribar and Collins (2002), we calculate total accruals using the data obtained directly from the cash flow and income statements. Total accruals of firm $i$ at time $t$ are defined as:

$$
T A C C_{i t}=\left[E B X I_{i t}-O C F_{i t}\right] / A_{i t-1}
$$

where $E B X I$ is earnings before extraordinary items and discontinued operations (COMPUSTAT item 76). $O C F$ is operating cash flow (from continuing operations) taken directly from the cash flows statement (COMPUSTAT item 108 - COMPUSTAT item 78). $A$ is total assets (COMPUSTAT item 44).

Unexpected total accruals are estimated by the cross-sectional, modified Jones model (Jones, 1991; Dechow, Sloan, and Sweeney, 1995), using two-digit Standard Industrial Classification (SIC) codes. Unexpected accruals are the difference between realized accruals and predicted (normal) accruals (scaled by assets at the beginning of the quarter). The quarter of the last earnings announcement before the offering announcement is labeled $\mathrm{Q}(-1) . \mathrm{Q}(0)$ is the quarter of the first earnings announcement after the offering announcement. All other quarters are similarly indexed relative to the offering announcement. A more detailed time line is described in Figure 1. We obtain earnings announcement dates from COMPUSTAT and the DJI database. We need SEO announcement dates and earnings announcement dates to calculate unexpected accruals and post-issue returns.

Normal accruals in the event quarter are estimated as: ${ }^{11}$

$$
N D A_{i t}=\alpha_{1}\left(1 / A_{i t-1}\right)+\alpha_{2}\left(\Delta R E V_{i t} / A_{i t-1}-\Delta R E C_{i t} / A_{i t-1}\right)+\alpha_{3}\left(P P E_{i t} / A_{i t-1}\right)
$$

where $\triangle R E V$ is changes in revenue from the previous quarter, $\triangle R E C$ is changes in net receivables from the previous quarter, $P P E$ is gross property plant and equipment, $A$ is total assets, and $\alpha_{1}, \alpha_{2}, \alpha_{3}$ are firmspecific parameters from the first-stage regression. Estimates of the firm-specific parameters are 
generated using the following model and contemporaneous data of non-offering firms with the same twodigit SIC code as the sample firm. ${ }^{12}$

$$
T A C C_{j t}=a_{1}\left(1 / A_{j t-1}\right)+a_{2}\left(\Delta R E V_{j t} / A_{j t-1}\right)+a_{3}\left(P P E_{j t} / A_{j t-1}\right)+v_{j t}
$$

where $a_{1}, a_{2}, a_{3}$ denote the OLS estimates of $\alpha_{1}, \alpha_{2}, \alpha_{3}$. Unexpected accruals are calculated as:

$$
D A_{i t}=T A C C_{i t}-N D A_{i t}
$$

The median, unexpected accruals are significantly positive at the $1 \%$ level in quarters $Q(+1)$ and $\mathrm{Q}(+2)$ and the greatest during the one-year period from $\mathrm{Q}(-1)$ to $\mathrm{Q}(+2)$. Rangan (1998), DuCharme et al. (2004), and Jo and Kim (2006) argue that managers have incentives to manage earnings in the later quarters, even after the offering announcement, because of concerns regarding lawsuits and 'lock-up agreements' (usually 90 to 180 days after a SEO) with underwriters. Teoh et al. (1998a) also argue that incentives to manage earnings are likely to persist in the months immediately after the offering. Consistent with those studies, we calculate the annualized unexpected accruals $\left(D A_{0}\right)$ for the one-year period, $\mathrm{Q}(-1)$ through $\mathrm{Q}(+2)$, around the offering announcement.

Table 2 presents the descriptive statistics of the selected variables used in the regression analyses for a full sample of 590 offerings. The $C M$ ranking is the Carter and Manaster (1990) measure of underwriter prestige, as updated by Carter et al. (1998). The rankings range from 0 to 9 , with 0 representing underwriters with the lowest prestige. The mean $C M$ reputation ranking for our sample is 8.13 with a median of 8.75 , indicating that, on average, SEO firms hired relatively high-quality underwriters during the sample period. As a proxy for earnings management, the mean and median $D A_{0}$ are $1.90 \%$ and $1.54 \%$ of the lagged total assets, respectively. These statistics suggest that, around their offerings, seasoned equity issuers boost their earnings by almost $2 \%$ of assets through unexpected accruals. The magnitude of the $D A_{0}$ is statistically significant at the $1 \%$ level. During the sample period, the mean (median) value of $A R_{l}$, the market-adjusted returns compounded daily over the one-year period after the $\mathrm{Q}(+2)$ earnings announcement, is $-18.18 \%(-18.48 \%)$, indicating that equity-offering firms experience significant price declines after their offerings. This is consistent with prior research (Brav et al., 2000; Loughran and Ritter, 1995 \& 1997; Spiess and Affleck-Graves, 1995). 
$\triangle R O A_{1}$ shows a negative mean value (-1.69\%), with a median value of $-0.99 \%$. These findings

indicate that, on average, issuing firms tend to experience poor post-issue operating performance as well. SEO firms show positive operating cash flows during the period of offerings. The mean value of OCFlow, cash flows from operating activities summed over $\mathrm{Q}(-1)$ to $\mathrm{Q}(+2)$ and scaled by assets at the beginning of $\mathrm{Q}(-1)$, is $2.13 \%$, with a positive median value of $7.20 \%$. For our full sample, the mean and median offer size, measured as offered shares divided by the number of pre-issue shares outstanding, is $26.86 \%$ and 19.90\%, respectively. These statistics are similar to those suggested by Altınkılıç and Hansen (2003) and Corwin (2003).

\section{Empirical results}

\subsection{Bivariate relations}

Table 3 presents the bivariate relations among underwriter reputation and earnings management, and other selected variables. The upper-triangle presents Pearson correlations and the lower-triangle summarizes the Spearman correlations of variables. Notably, the updated Carter and Manaster $(C M)$ measure shows a significantly negative correlation with unexpected total accruals $\left(D A_{0}\right)$, indicating that earnings management is a decreasing function of underwriter reputation and vice versa. $C M$ is also significantly positively associated with post-issue returns. Overall, this suggests that our bivariate results are consistent with our predictions 1 and 2 (a). In addition, consistent with Teoh et al. (1998a, 1998b) and Rangan (1998), we find an inverse relation between unexpected accruals and post-issue returns.

To gain quick insight into the relations among underwriter reputation, earnings management, and post-issue performance, we report $D A_{0}$ and the one-year, post-issue returns $\left(A R_{l}\right)$ for 30 individual underwriters in Panel A of Table 4. Based upon individual $C M$ reputation rankings, 30 individual underwriters are classified into three categories: the top 10, the middle group 10, and the lowest 10 reputed underwriters. In particular, the top 10 investment bankers underwrite more than $44 \%$ of our sample SEOs, while the lowest 10 bankers underwrite only 3.22\%. Notice also that Goldman Sachs alone underwrites 45 (7.63\%) offerings during the sample period. As expected, the mean value of $D A_{0}$ for the top 10 (bottom 10) 
underwriter group is the smallest (largest), while the mean value of $A R_{l}$ for the top 10 (bottom 10) underwriter group is the largest (smallest). These results suggest a negative relation between underwriter reputation and earnings management, supporting our prediction 1, and a positive relation between underwriter reputation and post-issue performance, supporting our prediction 2 (a). In addition, the differences in earnings management and post-issue performance between the top 10 and the lowest 10 underwriters are statistically significant. These results suggest the existence of heterogeneity, in which various types of underwriters systematically underwrite different types of securities.

In Panel B of Table 4, the 590 SEOs are classified into four groups based on their CM reputation rankings. The lowest (highest) group consists of SEOs underwritten by underwriters with a $C M$ rank that belongs to the first (fourth) quartile. The other two groups form the middle groups. The patterns are consistent with those in Panel A. Thus, the above preliminary results based upon various bivariate relations are consistent with our predictions. In the next section, we report the results based upon simultaneous association.

\subsection{The simultaneous relation between underwriter reputation and earnings management}

Considering potential endogeneity, we employ a structural model for an empirical representation of the relation between underwriter reputation, based upon the updated Carter and Manaster measure, and earnings management, proxied by unexpected total accruals. To reduce the possibility of model misspecification due to missing variables, we control for additional variables in the model, following prior research.

Fernando et al. (2005) find that firm size and quality affect the choice of underwriters. Thus, to control for those effects, we include firm size (Size) and return on assets (ROA) as a proxy of firm size and quality. Carter and Manaster (1990) and Fernando et al. (2005) suggest that more prestigious underwriters are able to market larger offerings of equity. Accordingly, we add an independent variable of offer size (Off_Size) to the regression to control for any systematic influence that this variable may have. Balvers et al. 
(1988) suggest that high-reputation underwriters use high-quality auditors more frequently. To control for the effect of auditor quality, we include an additional variable, NONB6 (an indicator variable of auditor quality set to equal 1 for non-big-six auditor, 0 otherwise). We predict that firms with growth opportunities will be more inclined to select high-quality underwriters to convey valuable information to shareholders. Thus we incorporate several control variables for investment opportunities into the regression equations, including Chung and Pruitt's (1994) measure of Tobin's q. This measure of Tobin's q is consistent with those of Gompers, Ishii, and Metrick (2003) and Oxelheim and Randøy (2003). Skinner (1993) shows that several proxies of the investment opportunity set are associated with a firm's accounting procedure choice. Following this literature, we include $R \& D$ intensity $(R \& D)$ and Tobin's $q$ in both the underwriter reputation and the earnings management regressions.

Numerous studies have documented that unexpected accruals are negatively associated with operating cash flow, change in performance, and auditor quality (Dechow, 1994; Burgstahler and Dichev, 1997; Becker et al. 1998). We thus include operating cash flow, change in ROA, and auditor quality as explanatory variables. In addition, previous research suggests that the incentive to manipulate earnings upward is smaller for larger firms because they are more politically sensitive and any earnings management is more likely to be detected (Watts and Zimmerman, 1978; Zmijewski and Hagerman, 1981). Earnings management might increase when firms are close to violating debt covenants. We use the debt-to-equity ratio, $L E N D$, to proxy the closeness to a debt-covenants violation.

If simultaneity among variables is ignored and the ordinary least square (OLS) is applied to estimate the parameters of a system of simultaneous equations, the estimates will be biased and inconsistent. Thus, we employ the three-stage least squares (3SLS) estimation approach to estimate the following simultaneous equations:

$$
\begin{aligned}
C M= & a_{0}+a_{1} D_{0}+a_{2} \text { NONB6 }+a_{3} \text { ROA }_{0}+a_{4} \text { Size }+a_{5} \text { Off_Size }+a_{6} R \& D+a_{7} \text { Tobin's } q \\
& +a_{8} \text { Industry dummies } \\
D A_{0}= & a_{0}+a_{1} \text { CM }+a_{2} \text { NONB6 }+a_{3} \text { OCFlow }_{0}+a_{4} \Delta R O A_{1}+a_{5} \text { Size }+a_{6} \text { LEND }+a_{7} R \& D \\
& +a_{8} \text { Tobin's } q+a_{9} \text { Industry dummies }
\end{aligned}
$$

where $C M$ is the Carter-Manaster reputation ranking; $D A_{0}$ is unexpected accruals summed over $\mathrm{Q}(-1)$ to 
$\mathrm{Q}(+2)$ and scaled by assets at the beginning of $\mathrm{Q}(-1), N O N B 6$ is an indicator variable of auditor quality, which is set to equal 1 for a NON-Big 6 auditor, and 0 otherwise, $R O A_{0}$ is $\operatorname{Year}(0) R O A$, measured as income before extraordinary items summed over $\mathrm{Q}(-1)$ to $\mathrm{Q}(+2)$ and scaled by assets at the beginning of $\mathrm{Q}(-1)$, Size is the $\log$ of the market value of equity at the beginning of Q(-1), Off_Size is the number of shares offered divided by the number of shares outstanding before the offering, $R \& D$ is the $R \& D$ intensity in the last fiscal year ending before the SEO announcement and calculated as the ratio of the annual R\&D expenditures to total sales, Tobin's $q$ is Chung and Pruitt's (1994) measure of Tobins' $q$, ${ }^{13}$ OCFlow $_{0}$ is cash flows from operating activities summed over $Q(-1)$ to $Q(+2)$ and scaled by assets at the beginning of $\mathrm{Q}(-1), \triangle R O A_{1}$ is changes in $R O A$, measured as year (1) $R O A$ - year (0) $R O A$, Year (1) $R O A$ is income before extraordinary items summed over $\mathrm{Q}(+3)$ to $\mathrm{Q}(+6)$ and scaled by assets at the beginning of $\mathrm{Q}(+3){ }^{14}$ and LEND is long-term debt over total stockholders' equity.

An inspection of the order and rank conditions reveals that both equations are identified (see Judge et al. (1982) for a discussion). The Hausman test statistic for the endogeneity check is 193.9, and it is statistically significant at the $1 \%$ level, providing evidence of simultaneity. Table 5 presents the results of association between underwriter reputation and earnings management based on the estimation of simultaneous equations. In model (1), the results show that the included variables jointly account for $36.51 \%$ of the variation in underwriter reputation and earnings management. As hypothesized, there is a significant, negative relation between underwriter reputation and earnings management $(\mathrm{t}$-value $=-5.61$ to -6.79). The results support our first prediction that underwriter reputation is negatively related to earnings management.

Because prestigious underwriters are not easily accessible to small firms, small firms typically do not hire high-quality underwriters. For instance, highly reputable underwriters might not select small companies with growth opportunities and potential for future success due to firm size. As a result, we expect a positive relation between underwriter reputation and firm size. The results show that firm size is positively associated with underwriter reputation. In model (1), we also find that $D A_{0}$ is positively associated with firm size. The result of the relation between DA and firm size is mixed. Although prior 
research documents that DAs are negatively associated with firm size, some studies report a positive relation between these two variables (e.g., DeFond and Park, 1997; Becker et al., 1998). However, firm size can proxy many different things. One possibility is that the relation between $D A_{0}$ and firm size is different for SEO firms. Another possibility is that multicollinearity affects the sign of the coefficient on the size variable and possibly other variables as well.

To investigate these issues more closely, we conduct additional tests by excluding firm size in model (2). We find that, even after we exclude the firm size variable from the $D A_{0}$ equation in Table 5, we continue to find the negative association between underwriter reputation and unexpected accruals. Overall, a potential firm size bias does not appear to change our inferences concerning the association between underwriter reputation and a proxy for earnings manipulation.

Recently, Hahn and Hausman $(2002,2003)$ and the other extant literature on "weak instruments" indicate that if instruments are only weakly correlated with the included endogenous variables and the degree of endogeneity is not strong enough, statistical inference based on simultaneous equation systems will pose a significant bias. Donald and Newey (2001) and Stock, Wright, and Yogo (2002) recommend culling the weak instruments using only the strong variables. Hahn and Hausman (2003) also suggest using an estimate of the reduced-form parameters of only the endogenous instrumental variables is better than using all the instruments. Accordingly, we set aside the weak instruments and use only the significant variables in our simultaneous models.

In model (3), following the recommendation of Hahn and Hausman (2003) and others regarding the potential cure for the weak instrument problems, we exclude the insignificant variables of $L E N D$, $R \& D$, Tobin's $q$, and firm size in the $D A_{0}$ equation and we remove $N O N B 6$ in the CM regression to keep only the significant variables. The results reported in model (3) confirm that underwriter prestige is negatively associated with earnings management. Therefore, the potential weak instrument problem does not change our inferences concerning the simultaneous association between underwriter reputation and earnings management. 
Table 6 presents the results of the simultaneous association between underwriter reputation and earnings management using two alternative measures of earnings management, $D A_{q-10}$ and $A d j D A_{0}$ as dependent variables in our earnings management equations. First, in order to examine the potential impact of different measurement windows of earnings management on the hypothesized association, we replace $D A_{0}$ with $D A_{q-10}$, unexpected accruals summed over $\mathrm{Q}(-1)$ and $\mathrm{Q}(0)$ and scaled by assets at the beginning of Q(-1), following Kim and Park (2005). Kim and Park (2005) use discretionary accruals over two quarters, $\mathrm{Q}(-1)$ and $\mathrm{Q}(0)$, to test whether equity issuers employing aggressive accounting decisions also more aggressively push up their offer prices, thereby leading to a decrease in underpricing. In Kim and Park (2005), Q(-1) is defined as the last quarter for which a financial statement is available at the time of the offer, and we define $\mathrm{Q}(-1)$ as the last quarter for which earnings are announced prior to the offering announcement. Though time references are not matched perfectly, the closest accrual measurement window is $Q(-1)$ and $Q(0)$ in our study.

Second, we estimate earnings management with performance-adjusted discretionary total accruals, as suggested by Kothari et al. (2005). They show that existing methods for estimating discretionary accruals are biased toward rejecting the null hypothesis of no earnings management when the event related to the incentive is associated with performance. Kothari et al. (2005) recommend adjusting discretionary accruals by subtracting discretionary accruals of control firms matched on prioryear ROA and industry. Following Kothari et al. (2005), we match each SEO firm with a non-SEO firm from the same industry (using the two-digit SIC code), with the closest ROA (net income divided by lagged total assets) in the year ending prior to $\mathrm{Q}(-1) . A d j D A_{0}$ is the unexpected accruals of the SEO firm minus the unexpected accruals of the performance matched, non-SEO firm, summed over $\mathrm{Q}(-1)$ to $\mathrm{Q}(+2)$ and scaled by assets at the beginning of Q(-1).

As shown in Table 6, we continue to find an inverse association between underwriter reputation and earnings management for both alternative measures. Thus, our inferences relating to underwriter reputation and earnings management are unaffected when these alternative measurements of earnings management are employed. 


\subsection{Additional tests with AAER data}

Dechow et al. (1996) investigate the motivation of earnings management based on the Accounting and Auditing Enforcement Releases (AAERs). Though not all instances of earnings management are violations of Generally Accepted Accounting Principles (GAAP), demonstrating that SEO firms with less-prestigious underwriters are more likely to be subject to SEC enforcement actions will reinforce our findings on the effect of underwriter quality on earnings management. For 590 offerings in the final sample, we identify offerings that are subject to AAERs through a LexisNexis search. Issuers of 25 offerings are subject to one or more AAERs during the period between one year prior to the offer date and December 2004. We read all of the AAERs that are related to these 25 offerings. We find that only one offering is subject to the AAER due to the misreporting of a financial statement related to the offer. The underwriter reputation score for this offering is 5.17 , which is much lower than 8.13 , the sample's mean reputation score. The $\mathrm{DA}_{0}$ of the offering with AAER is 0.2142 , which is much higher than 0.0190 , the mean $\mathrm{DA}_{0}$ of the sample and the offerings without AAERs. However, because we have only one offering that is subject to AAER, it is difficult to draw any conclusion from this analysis.

To further investigate the association between underwriter reputation and the incidence of AAERs, we conduct an out-of-sample test. We expand the analysis to include all equity offerings, both IPOs and SEOs, during the ten-year period between 1988 and 1997. We first search for offerings that are subject to AAERs. We have over 2,000 AAERs by the end of 2004. We use the keyword "offering" to identify 335 offering-related AAERs. Eighty-eight AAERs are eliminated because they are related to debt offerings, private placements, and are not related to the misreporting of financial statement at the time of or just prior to the offer. A single case in which a financial statement is misreported can cause multiple AAERs: one to the company that prepared the false financial statement and the other to the auditor, etc. One hundred-three AAERs are eliminated to exclude the multiple AAERs for each offering. Of the remaining 144 AAERs, or 144 public equity offerings associated with AAERs, 76 are related to the offers issued during the ten-year period between 1988 and 1997. We match these 76 offerings with public equity 
offering data from the SDC database. Eighteen offerings are not matched with SDC data either because the offering is only considered and never filed with SEC or because the offering is withdrawn, or for other reasons. Carter-Manaster ranking data are not available for 26 of the remaining 58 offerings. Thus the final number of offerings that are subject to AAERs is 32. This sampling process is described in Panel A of Table 7.

The Carter-Manaster rankings of the offerings that are subject to AAERs are compared to those of the offerings that are not subject to AAERs. We have 10,214 public equity offerings, 5,308 IPOs, and 4,906 SEOs between 1988 and 1997. After eliminating 3,194 offerings without underwriter reputation scores, we have 7,020 equity offerings. Of 7,020 offerings (3,459 IPOs and 3,561 SEOs), 32 (23 IPOs and 9 SEOs) are subject to AAERs, and 6,988 (3,436 IPOs and 3,552 SEOs) are not. Panel B shows the number of public equity offerings in each category.

Panel $\mathrm{C}$ shows the underwriter reputation scores of offerings with AAERs and those of offerings without AAERs. The mean underwriter reputation score of offerings that are subject to AAERs is 7.41. The mean reputation score of offerings that are not subject to AAER is 8.01. The difference is statistically significant based on a t-test (one-tailed) and a Wilcoxon two-sample test (one-tailed) at the conventional level. We also replicate the same analysis separately for IPOs and SEOs. The mean underwriter reputation score of IPOs with AAERs is 7.40. The mean reputation score of IPOs without AAERs is 7.87. The difference is marginally significant based on a t-test (one-tailed) and insignificant based on a Wilcoxon test (one-tailed). The mean underwriter reputation score of SEOs with AAERs is smaller than the score of SEOs without AAERs and the difference is marginally significant based on a t-test and a Wilcoxon twosample test. The less-significant results might be due to the smaller sample size (of offerings with AAERs) when analyses are conducted separately for IPOs and SEOs.

Overall, our results from the out-of-sample tests suggest that issuers of offerings that are subject to AAERs are more likely to employ less-prestigious underwriters. This result provides additional support for the inverse association between earnings management and underwriter reputation, and thus reinforces the earnings management interpretation of the accrual results. 


\subsection{Regression results of post-issue return and operating performance}

Our prediction 2 (a) posits that, after controlling for earnings management, the post-issue returns of seasoned equity issuers with more prestigious underwriters are expected to decline less than those of SEO firms with low-quality underwriters. To examine the above assertion, we first measure the post-issue returns by compounding the daily market-adjusted returns over the one-year period after the $Q(+2)$ earnings announcement. Next, we regress the post-issue return performance on underwriter reputation, earnings management, and control variables as follows:

$$
A R_{1}=b_{0}+b_{1} C M+b_{2} D A_{0}+b_{3} R O A_{0}+b_{4} \Delta R O A_{1}+b_{5} F E O 2+b_{6} S i z e+b_{7} B M
$$

where $A R_{I}$ is the market-adjusted returns compounded daily over the one-year period after the $\mathrm{Q}(+2)$ earnings announcement, FEO2 is an indicator variable that takes the value of 1 if the firm accesses the equity market to raise additional capital during the two-year period after the seasoned equity offering, and 0 otherwise, and $B M$ is the book-to-market ratio at the beginning of $\mathrm{Q}(-1)$. All other variables are the same, as previously defined. If a firm expects to access the equity market in the near future, an immediate decline in stock price after the offer can work negatively for future offerings. The firm expecting equity offers in the near future is more likely to prevent this from happening. Hence we expect that post-offering underperformance will be less for firms expecting equity offers shortly after the current offerings. Thus, we include FE02, an indicator variable that takes 1 if the firm accesses the equity market to raise additional capital during the two-year period after the SEO.

Table 8 reports the regression results. The results presented in models (1) and (2) demonstrate that underwriter reputation is positively associated with post-issue return performance, and it has a distinct effect separate from the effect of earnings management on post-issue performance. The results are consistent with our prediction that a high-quality underwriter fulfills a strict monitoring role, lessens information asymmetry by closing the information gap between managers and investors, and therefore, reduces the extent of post-issue SEO underperformance. Consistent with previous research (Teoh et al., 1998a \& 1998b; Rangan, 1998), we find that $D A_{0}$ is negatively related to post-issue performance (see 
models (2) and (4)). As reported in model (4) of Table 8, the results remain unchanged, even after controlling for the industry effect.

Prediction 2 (b) asserts that, with the underwriter's certification and monitoring roles, post-issue returns of seasoned equity issuers with more prestigious underwriters and conservative earnings management underperform less than those of SEO firms with low-quality underwriters and aggressive earnings management. Thus, we examine the joint impact of underwriter quality and issuers' earnings management on post-issue stock performance.

In model (3) of Table 8, instead of $C M$ and $D A_{0}$, we include two dummy variables, $D 1$ and $D 2$, to examine the joint impact of the issuing firms' underwriter choice and earnings management. We rank issuers by their underwriter $C M$ ranking and unexpected accruals and select two extreme groups of issuers from the quartiles of $C M$ and $D A_{0}$. We then estimate the following model:

$$
A R_{1}=b_{0}+b_{1} R O A_{0}+b_{2} \Delta R O A_{1}+b_{3} F E O 2+b_{4} \text { Size }+b_{5} B M+b_{6} D 1+b_{7} D 2
$$

where $D 1$ is an indicator variable that takes the value of 1 if an issuer selects the highest-quality underwriter $(C M>=$ third quartile $)$ and the most conservative earnings manager $\left(D A_{0}<\right.$ first quartile $)$, and 0 otherwise. $D 2$ is an indicator variable that takes the value of 1 if an issuing firm hires the lowest-quality underwriter $\left(C M<\right.$ first quartile) and the most aggressive earnings manager ( $D A_{0}>=$ third quartile), and 0 otherwise. All other variables are the same, as defined in the previous section.

As predicted, we find a joint effect of an issuer's underwriter choice and its earnings management on post-issue performance. As presented in model (3) of Table 8, the coefficient for D1 is positive and significant at the $5 \%$ level. The results suggest that seasoned equity issuers with the most prestigious underwriters and the most conservative earnings management experience higher post-issue performance than do those otherwise defined. We interpret this to indicate that the highest-quality underwriter and the most conservative earnings management jointly reduce post-issue underperformance. Conversely, $D 2$, the group with the lowest-quality underwriter and the most aggressive earnings management, shows a negative and significant coefficient. The results indicate that the lowest-quality underwriter and the most aggressive earning management together significantly reduce post-issue returns. Overall, these findings 
support our prediction 2 (b). We find that post-issue returns are positively related to the operating performance measures of $R O A_{0}$ and $\triangle R O A_{1}$. In various model specifications, the coefficients on these variables are all statistically significant at the $1 \%$ level. FEO2 is also positively associated with post-issue returns, indicating that when firms intend to access the equity market to raise additional capital shortly after the current offerings, their post-issue return underperformance is less severe.

We also examine how underwriter quality is related to post-issue operating performance. For this task, we regress a measure of operating performance in the post-offering period, $\triangle R O A_{1}$, on underwriter reputation, unexpected total accruals, and two control variables, sales growth and growth in capital expenditures, following Rangan (1998). We then estimate the following equation:

$$
\triangle R O A_{1}=\beta_{0}+\beta_{1} C M+\beta_{2} D A_{0}+\beta_{3} S G R O A+\beta_{4} C A P G R O A
$$

where $S G R O A$ is the percentage growth rate in sales from year(-1) to year(0). Sales for year(0) is net sales summed over $\mathrm{Q}(-1)$ to $\mathrm{Q}(+2)$ and sales for year(-1) is net sales summed over $\mathrm{Q}(-5)$ to $\mathrm{Q}(-2)$. CAPGROA is the percentage growth rate in capital expenditures from year(-1) to year(0). Other variables are the same as defined earlier.

Table 9 reports the results. $C M$ is positively associated with $\triangle R O A_{1}$, indicating that prestigious underwriters have a positive impact on the operating performance in the post-offering period. The coefficient on $D A_{0}$ is negative and significant at the $1 \%$ level. CAPGROA shows a negative relation to $\triangle R O A_{l}$. This is consistent with Rangan (1998). Together, the evidence suggested in Tables 8 and 9 indicates that after controlling for earnings management, the choice of underwriter has an incremental impact on issuers' post-issue stock and operating performance.

\subsection{Evidence on post-issue, long-term return performance}

To check if the relation between underwriter reputation and post-issue return lasts beyond the first year, we examine the long-term, post-issue return performance for up to five years after the active earnings management period around the SEO. Carter et al. (1998) examine the relation between underwriter 
reputation and the three-year returns following IPOs. They provide empirical evidence that underwriter reputation is positively related to long-run returns. By employing three-year, holding-period returns, McLaughlin et al. (2000) investigate the relation between underwriter reputation and long-run, post-issue stock price performance in firms conducting SEOs. They find no significant relation between the two.

We first categorize the four groups based upon underwriter reputation and the level of earnings management. If $C M$ is greater than or equal to the median value and $D A_{0}$ is greater than or equal to the median value, then the sample is classified into group 1. If $C M$ is greater than or equal to the median value and $D A_{0}$ is less than the median value, then the sample is classified into group 2. If $C M$ is less than the median value and $D A_{0}$ is greater than or equal to the median value, then the sample is classified into group 3. If $C M$ is less than the median value and $D A_{0}$ is less than the median value, then the sample is classified into group 4. We choose the two extreme groups: groups 2 and 3.

We then follow the Fama and French (1993) three-factor model approach and run the following regression for individual securities in each group:

$$
\left(R_{i t}-R_{f t}\right)=\alpha+b_{1}\left(R_{m t}-R_{f t}\right)+b_{2} S M B_{t}+b_{3} H M L_{t}+e_{i t}
$$

where $R_{i t}$ is the monthly return of SEO firm $i . R_{f t}$ is one month treasury bill rate. $R_{m t}-R_{f t}$ is the market excess return in month $t . S M B_{t}$ is the difference between the month $t$ return on a value-weighted portfolio of small stocks and one of large stocks. $H M L_{t}$ is the difference between the month $t$ return on a valueweighted portfolio of high book-to-market stocks and one of low book-to-market stocks, and $e_{i t}$ is the error term.

Table 10 presents the long-term, post-issue results for the four groups. Panel A reports the first year buy-and-hold returns, and the $\alpha$ coefficients from the Fama \& French three-factor model estimated over 12-month, 24-month, 36-month, 48-month, and 60-month periods after the $\mathrm{Q}(+2)$ earnings announcement. The results show that, based upon buy-and-hold returns, the SEO underperformance is significant in groups 1,3 , and 4 in the first year after the active earnings management period around the SEO. However, when we control the associated risks using the Fama \& French factors, post-issue return underperformance disappears in group 1 in one- and two-year horizons. It then becomes significantly 
negative in the three- and four-year horizons. We find that firms in groups 3 and 4 experience significant underperformance in post-issue returns up to two or three years after their offerings.

To perform difference tests between groups, we conduct t-tests and Wilcoxon tests of one-year, buy-and-hold returns and monthly excess returns. First, we compare two extreme groups: group 2 (high underwriter reputation and low earnings management) and group 3 (low underwriter reputation and high earnings management). Next, we control earnings management on the low side and compare groups 2 and 4, so that we can examine the effect of underwriter reputation only. Similarly, we control earnings management on the high side by comparing groups 1 and 3. Panel B summarizes both the t-statistic and Wilcoxon test statistics for differences in post-issue returns. The differences in the one-year, buy-andhold returns are significant in two cases (group 2 versus 3, and group 2 versus 4). Monthly abnormal returns from the Fama \& French three-factor model estimated over 12 months are also significant in these two cases. Overall, this evidence is consistent with previous results and our predictions 2 (a) and 2 (b). However, the effect of underwriter reputation does not last long. In particular, difference tests indicate that $\alpha$ coefficients from the Fama \& French three-factor model estimated over 24-month, 36-month, 48month, and 60-month periods are not different across groups.

It is puzzling that in Table 10, long-term underperformance lasts until year 4 for the high EM and high CM group, while it only lasts until year 2 in the high EM and low CM group. This seems inconsistent with the earlier results. The post-issue underperformance resulting from high EM is more intense in year 1 for the low CM group than the high CM group. However, it seems that the EM effect lasts longer in the high $\mathrm{CM}$ group than in the low $\mathrm{CM}$ group. We interpret the results as follows. For the high CM, high EM group, post-issue performance of the issuers with the most aggressive EM will be worse off and returns will adjust to that. However, underwriters' high reputation helps reduce a dramatic decline in the long-term performance immediately after the offerings, and therefore the underperformance lasts longer. Firms in the low CM, high EM group do not enjoy protection from high-reputation underwriters, and therefore experience a significant drop in the post-issue return adjustment shortly after offerings. 


\section{Summary}

For new equity issuers, the underwriter's certification and monitoring roles are important. Since highreputation underwriters act as credible certifiers of information regarding equity-issuing firms for lessinformed investors, equity issuers attempt to reduce investor uncertainty about the firms' value by hiring prestigious underwriters. Reputable underwriters have an incentive to minimize an issuer's aggressive earnings management to protect their reputation capital and reduce litigation costs. Accordingly, issuers that intend to engage in aggressive earnings management select underwriters with lower reputations.

We empirically examine the relation between underwriter choice and incentives for earnings management around SEOs and its impact on post-issue performance. We predict that there is an inverse association between underwriter reputation and earnings management and a positive relation between underwriter reputation and post-issue performance, and that the post-issue returns of firms with highquality underwriters and conservative earnings management are higher than those of firms with lowquality underwriters and aggressive earnings management.

Consistent with these predictions, we find that (1) underwriter reputation is a decreasing function of the incentive for earnings management and vice versa. We interpret these results to mean that issuers with minimal incentives for earnings management hire high-quality underwriters, while high-reputation underwriters inhibit aggressive earnings management. Conversely, aggressive earnings managers invite low-quality underwriters to avoid stringent monitoring; (2) underwriter reputation has a positive impact on post-issue returns and operating performance after controlling for earnings management and other confounding effects. However, the effect of underwriter reputation on post-issue returns does not last long; (3) seasoned equity issuers with the lowest-quality underwriters and the most aggressive earnings management experience more dramatic declines in post-issue return performance than firms using the most prestigious underwriters and the most conservative earnings management. 


\section{Acknowledgements}

We are grateful to the editor, Richard G. Sloan, two anonymous referees, Michael Calegari, Jay Jongmoo Choi, Michael Eames, and Jun-Koo Kang for many valuable comments. We also thank Arno Forst, Yesim Genturck, and Weilu Huang for their research assistance. Jo acknowledges financial support from the Dean Witter Foundation. Kim acknowledges support from the Accounting Development Fund at Santa

Clara University. Park acknowledges financial support from the School of Business at Virginia Commonwealth University. 


\section{Notes}

${ }^{1}$ For example, Healy (1985) documents that in a costly contract setting, managers adjust discretionary accruals to report a high level of earnings.

${ }^{2}$ Schipper (1989) defines earnings management as "purposeful intervention in the external reporting process, with the intent of obtaining some private gain to managers or shareholders." Healey and Wahlen (1999) define earnings management as follows: Earnings management occurs when managers use judgment in financial reporting and in structuring transactions to alter financial reports to either mislead some stakeholders about the underlying economic performance of the company, or to influence contractual outcomes that depend on the reported accounting numbers. We follow these definitions of earnings management throughout the paper.

${ }^{3}$ Since firms conducting SEOs are usually larger, older, and better covered by analysts than IPOs, the underwriter reputation concern might be more serious in SEOs.

${ }^{4}$ We acknowledge that it is not entirely a firm's decision to select the underwriters. Fernando et al. (2005) suggest that issuers and underwriters mutually select each other. We examine whether prestigious underwriters avoid equity issuers with aggressive pre-SEO earnings management in the later analyses. In addition, due to the fact that high-quality underwriters are not equally accessible to small firms, it is more difficult for small firms to hire prestigious underwriters. Thus, we control the size variable in the following analyses.

${ }^{5}$ Zhou and Elder (2004) provide evidence of the negative relation between auditor quality and earnings management around the SEOs. Though high-reputation underwriters use high-quality auditors more frequently (Balvers et al., 1988), we argue that the effect of underwriter reputation is distinct from that of auditor quality. As shown in Tables 5 and 6, after controlling for the auditor variable, underwriter reputation always shows a significant association with earnings management, and the association is stronger than that of the auditor variable. We find that the auditor variable becomes significant when 
the underwriter variable is dropped from the earnings management equation. Our findings are in line with the theory (Chemmanur and Fulghieri, 1994; Hansen and Torregrosa, 1992).

${ }^{6}$ Another possible interpretation is that well-known information-processing biases, like optimism, also play a role. As Dichev and Piotroski (2001) point out, optimism naturally results in more erroneous conclusions when applied to fairly negative situations, and thus negative situations are followed by subsequent, more extreme adjustments in stock prices.

${ }^{7}$ McLaughlin, et al. (2000) suggest that hiring a low-quality underwriter is a bad signal to the market. It is also known that the issues with low-quality underwriters are underpriced more. Therefore, issuers will hire low-quality underwriters only if the benefits of earnings management exceed the costs of not hiring reputable underwriters (Hansen and Torregrosa, 1992). Kim and Park (2005) provide empirical evidence that underpricing is smaller for issuers that aggressively manage earnings. Their result suggests that the benefits of earnings management exist.

${ }^{8}$ See the reduction of information asymmetries in an IPO context from Titman and Trueman (1986), Carter and Manaster (1990), Michaely and Shaw (1994), Chemmanur and Fulghieri (1994), and Carter et al. (1998), among others.

${ }^{9}$ Several studies, including Altınkılıç and Hansen (2003), Corwin (2003), and Mola and Loughran (2004), report that the underpricing of SEOs has become commonplace and that the magnitude of SEO underpricing has increased more dramatically in the 1990s than it did during earlier periods. Corwin (2003) documents that SEO underpricing increased to 2.92\% for offers during the 1990-1998 period from $1.15 \%$ for offers in the $1980 \mathrm{~s}$ and that the average reached a high of $3.72 \%$ in 1996.

${ }^{10}$ Though an updated list of the Carter-Manaster ranks is available on the Jay Ritter's web site, it is inappropriate for our sample offerings because Ritter's rankings are based on data up to 2000. Since our sample period ends in 1997, updated underwriter reputation rankings based on the deals up to 2000 are unavailable for issuers in our sample. 
${ }^{11}$ The change in revenues is adjusted for the change in receivables (equation 2), when the normal, current accruals are estimated. This implicitly assumes that all changes in uncollected credit sales at the end of the event period result from earnings management. The reasoning behind this modification is that earnings are easier to manage via credit sales than cash sales (Dechow et al., 1995).

${ }^{12}$ If there are less than 10 firms in the same two-digit industry group, then the observation is dropped to mitigate the error in the prediction model.

${ }^{13}$ Following Chung and Pruitt (1994), Tobin's $q$ is calculated as: $\{[$ Market value of common stock + Book value of preferred stock + Book value of long-term debt + Book value of current liabilities - (Book value of current assets - Book value of Inventories)] / Book value of total assets $\}$ in the last fiscal year ending before the SEO announcement.

${ }^{14}$ In equation (6), $\triangle R O A_{1}$ is the proxy for the expected changes in performance in the near future. If $\triangle R O A_{1}$ and unexpected accruals $\left(D A_{0}\right)$ are positively associated, then issuers manage earnings to signal their improving future performance. In such a case, the correlation between underwriter quality and unexpected accruals is not necessarily negative. In addition, DeFond and Park (1997) find that a firm's current accruals are inversely related to the firm's future earnings performance. Thus, if a firm expects that its performance is improving, it is less likely to use accruals to make its investor image more positive. To control these effects, $\triangle R O A_{1}$ is included in the regression. 


\section{References}

Altınkılıç, O. and R. Hansen. (2003). “Discounting and underpricing in seasoned equity offers.” Journal of Financial Economics 69, 285-323.

Balvers, R., B. McDonald and R. Miller. (1988). "Underpricing of new issues and the choice of auditor as a signal of investment banker reputation.” Accounting Review 63, 605-622.

Beatty, R. and J.R. Ritter. (1986). "Investment banking, reputation and the underpricing of initial public offerings.” Journal of Financial Economics 5, 261-281.

Becker, C.L., M.L. Defond, J. Jiambalvo and K.R. Subramanyam. (1998). "The effect of audit quality on earnings management." Contemporary Accounting Research 15, 1-24.

Block, D. J. and J. Hoff (1999). "Underwriter due diligence in securities offerings.” Cadwalader, Wickersham \& Taft LLP.

Booth, J.R. and R.L. Smith. (1986). "Capital raising, underwriting and the certification hypothesis." Journal of Financial Econimics 15, 261-281.

Brav, A., C. Geczy and P. Gompers. (2000). "Is the abnormal return following equity issuances anomalous?' Journal of Financial Economics 56, 209-250.

Burgstahler, D. and I.D. Dichev. (1997). "Earnings management to avoid earnings decreases and losses." Journal of Accounting and Economics 24, 99-126.

Carter, R.B., F.H. Dark and A.K. Singh. (1998). "Underwriter reputation, initial returns, and the long-run performance of IPO stocks.” Journal of Finance 43, 285-311.

Carter, R.B. and S. Manaster . (1990). "Initial public offerings and underwriter reputation.” Journal of Finance 45, 1045-1067.

Chan, K., J.W. Cooney, J. Kim and A.K. Singh. (2005). “The IPO Derby - Are there Consistent Losers and Winners on this Track?" Working paper, National Taiwan University.

Chemmanur, T.J. and P. Fulghieri. (1994). "Investment bank reputation, information production and financial intermediation." Journal of Finance 49, 47-79. 
Chung, K. and S.A. Pruitt. (1994). “A simple approximation of Tobin’s q.” Financial Management 23, $70-74$.

Cooney, J.W., H.K. Kato and J.S. Schallheim. (2003). "Underwriter certification and Japanese seasoned equity issues.” Review of Financial Studies 16, 949-982.

Corwin, S.A. (2003). "The determinants of underpricing for seasoned equity offers." Journal of Finance $58,2249-2279$.

Daniel, K., D. Hirshleifer and A. Subrahmanyam. (1998). "Investor psychology and security market under- and overreactions." Journal of Finance 53, 1839-1885.

Dechow, P. (1994). “Accounting earnings and cash flows as measures of firm performance: the role of accounting accruals." Journal of Accounting and Economics 18, 3-42.

Dechow, P., R.G. Sloan and A.P. Sweeney. (1995). “Detecting earnings management.” Accounting Review 70, 193-225.

Dechow, P., R.G. Sloan and A.P. Sweeney. (1996). "Causes and consequences of earnings manipulation: an analysis of firms subject to enforcement actions by the SEC." Contemporary Accounting Research 13, 1-36.

DeFond M. and C. Park. (1997). "Smoothing income in anticipation of future earnings.” Journal of Accounting and Economics 23, 115-139.

Dichev, I.D. and J.D. Piotroski. (2001). "The long-run stock returns following bond rating changes.” Journal of Finance 56, 173-203.

Donald, S. and W. Newey. (2001). "Choosing the number of instruments.” Econometrica 69, 1161-1191.

DuCharme L., P. Malatesta and S. Sefcik. (2004). "Earnings management, stock issues, and shareholder lawsuits." Journal of Financial Economics 71, 27-49.

Dunbar, C. (2000). "Factors affecting investment bank initial public offering market share." Journal of Financial Economics 55, 3-41.

Elder, R. and J. Zhou. (2002). “Audit firm size, industry specialization and earnings management by initial public offering firms." Working paper. Syracuse University. 
Fama, E.F. and K.R. French. (1993). "Common Risk Factors in the Returns on Stocks and Bonds.” Journal of Financial Economics 33, 3-56.

Fernando, C.S., V.A. Gatchev and P.A. Spindt. (2005). "Wanna dance? How firms and underwriters choose each other." Journal of Finance 60, 2437-2469.

Gompers, P., J. Ishii and A. Metrick (2003). “Corporate governance and equity prices.” Quarterly Journal of Economics 118, 107-155.

Hahn, J. and J. Hausman (2002). “A new specification test for the validity of instrumental variables.” Econometrica 70, 163-189.

Hahn, J. and J. Hausman (2003). "Weak instruments: Diagnosis and cures in empirical economics.” American Economic Review 93, 118-125.

Hansen, R. and P. Torregrosa. (1992). “Underwriter Compensation and Corporate Monitoring.” Journal of Finance 47, 1537-1555.

Healy, P. (1985). "The effect of bonus schemes on accounting decisions.” Journal of Accounting and Economics 7, 85-107.

Healy, P. and J. Wahlen. (1999). “A review of the earnings management literature and its implications for standard setting." Accounting Horizons 13, 365-383.

Hribar, P. and D.W. Collins. (2002). "Errors in estimating accruals: Implications for empirical research.” Journal of Accounting Research 40, 105-134.

Jo, H. and Y. Kim. (2006). “Disclosure frequency and earnings management.” Journal of Financial Economics, forthcoming.

Jones, J. (1991). “Earnings management during import relief investigations." Journal of Accounting Research 29, 193-228.

Judge, G., R. Hill, W. Griffiths, H. Lutkepohl and T. Lee. (1982), Introduction to the Theory and Practice of Econometrics, New York, NY, John Wiley \& Sons.

Kim, Y. and M. Park. (2005). "Pricing of seasoned equity offers and earnings management." Journal of Financial and Quantitative Analysis 40, 435-463. 
Kothari, S.P. (2001). "Capital markets research in accounting.” Journal of Accounting and Economics 31, $105-231$.

Kothari, S.P., A.J. Leone and C.E. Wasley. (2005). "Performance matched discretionary accrual measures." Journal of Accounting and Economics 39, 163-197.

Loughran, T. and J.R. Ritter. (1995). “The new issues puzzle.” Journal of Finance 50, 23-51.

Loughran, T. and J.R. Ritter. (1997). “The operating performance of firms conducting seasoned equity offerings." Journal of Finance 52, 1823-1850.

McLaughlin, R., A. Safieddine and G. Vasudevan. (2000). "Investment banker reputation and the performance of seasoned equity issuers." Financial Management 29, 96-110.

Michaely, R. and W.H. Shaw. (1994). "The pricing of initial public offerings: Tests of adverse selection and signaling theories.” Review of Financial Studies 7, 279-319.

Miller, G. (2000). Association response to NYS banking due diligence proposals, bondMarkets.com

Mola, S. and T. Loughran (2004), 'Discounting and clustering in seasoned equity offering prices', Journal of Financial and Quantitative Analysis, Vol. 39, No. 1, pp. 1-23.

Ng, C.K. and R.L. Smith. (1996). "Determinants of contract choice: The use of warrants to compensate underwriters of seasoned equity issues." Journal of Finance 51, 363-380.

Oxelheim L. and T. Randøy (2003). “The impact of foreign board membership on firm value.” Journal of Banking and Finance 27, 2369-2392.

Puri, M. (1996). "Commercial banks in investment banking: Conflict of Interest or certification role?.” Journal of Financial Economics 40, 373-401.

Rangan, S. (1998). "Earnings management and the performance of seasoned equity offerings." Journal of Financial Economics 50, 101-122.

Schipper, K. (1989). “Commentary on earnings management.” Accounting Horizons 3, 91-102.

Skinner, D.J. (1993). “The investment opportunity set and accounting procedure choice.” Journal of Accounting and Economics 16, 407-445. 
Slovin, M.B., M.E. Sushka and K.W.L. Lai. (2000). “Alternative flotation methods, adverse selection, and ownership structure: Evidence from seasoned equity issuance in the U.K." Journal of Financial Economics 57, 309-327.

Spiess, D. K. and J. Affleck-Graves. (1995). "Underperformance in long-run stock returns following seasoned equity offerings." Journal of Financial Economics 38, 243-267.

Stock, J. H., J. Wright and M. Yogo (2002). "A survey of weak instruments and weak identification in generalized method of moments." Journal of Business and Economic Statistics 20, 518-529.

Teoh S. H., I. Welch and T.J. Wong. (1998a). "Earnings management and the long-run market performance of initial public offerings.” Journal of Finance 53, 1935-1974.

Teoh S. H., I. Welch and T.J. Wong. (1998b). "Earnings management and the underperformance of seasoned equity offerings." Journal of Financial Economics 50, 63-99.

Titman, S. and B. Trueman. (1986). "Information quality and the valuation of new issues." Journal of Accounting and Economics 8, 159-172.

Watts, R.L. and J.L. Zimmerman. (1978). "Towards a positive theory of the determination of accounting standards.” Accounting Review 53, 112-134.

Watts, R.L. and J.L. Zimmerman. (1986). Positive Accounting Theory, Prentice-Hall, Englewood Cliffs, NJ.

Zhou, J. and R. Elder. (2004). “Audit quality and earnings management by seasoned equity offering firms." Asia-Pacific Journal of Accounting and Economics 11, 95-120.

Zmijewski, M.E. and R.L. Hagerman. (1981). “An Income Strategy Approach to the Positive Theory of Accounting Standard Setting/Choice.” Journal of Accounting and Economics 3, 129-49. 
Table 1. Sample characteristics of seasoned equity offerings

Panel A: Size characteristics

\begin{tabular}{lrcrrc} 
& $\begin{array}{r}\text { Total } \\
\text { assets }\end{array}$ & $\begin{array}{c}\text { Market } \\
\text { value }\end{array}$ & $\begin{array}{r}\text { Book } \\
\text { value }\end{array}$ & $\begin{array}{r}\text { Offer } \\
\text { amount }\end{array}$ & $\begin{array}{c}\text { Offer } \\
\text { size }\end{array}$ \\
\hline Mean & $1,113.16$ & 958.33 & 319.81 & 96.40 & 0.24 \\
Median & 207.59 & 263.86 & 78.64 & 53.79 & 0.19 \\
Std. Dev. & $4,107.89$ & $3,922.56$ & $1,013.86$ & 144.42 & 0.37 \\
\hline
\end{tabular}

Panel B: Time distribution

\begin{tabular}{rrr} 
Year & Frequency & $\%$ \\
\hline 1990 & 27 & 4.58 \\
1991 & 87 & 14.75 \\
1992 & 76 & 12.88 \\
1993 & 66 & 11.19 \\
1994 & 44 & 7.46 \\
1995 & 71 & 12.03 \\
1996 & 103 & 17.40 \\
1997 & 116 & 19.66 \\
\hline
\end{tabular}

Panel C: Industry distribution

\begin{tabular}{llrr} 
Industry & Two-digit SIC codes & Frequency & $\%$ \\
\hline Oil and gas & 13 & 71 & 12.03 \\
Food products & 20 & 7 & 1.19 \\
Paper and paper products & $24,25,26,27$ & 26 & 4.41 \\
Chemical products & 28 & 70 & 11.86 \\
Manufacturing & $30-34$ & 31 & 5.25 \\
Computer equipment and services & 35,73 & 63 & 10.68 \\
Electronic equipment & 36 & 47 & 7.97 \\
Transportation & $37,39,40-42,44,45$ & 37 & 6.27 \\
Scientific instruments & 38 & 28 & 4.75 \\
Communications & 48 & 26 & 4.41 \\
Electricity, gas, and sanitary services & 49 & 26 & 4.41 \\
Durable goods & 50 & 24 & 4.07 \\
Retail & $53,54,56,57,59$ & 54 & 9.15 \\
Eating and drinking establishments & 58 & 2 & 0.34 \\
Entertainment services & $70,78,79$ & 12 & 2.03 \\
Health & 80 & 16 & 2.71 \\
All others & & 50 & 8.47 \\
\hline
\end{tabular}


Table 1. continued.

The sample consists of 590 seasoned equity offerings of common stock by industrial US firms over the period 1990 through 1997. We terminate our SEO sample in 1997 in order to examine post-offering returns up to five years after the active earnings management period. Sample offerings are collected from the Securities Data Corporation (SDC) database. The total assets, market value of equity and book value of equity are measured at the end of the quarter before the offering announcement. The total assets, market value of equity, book value of equity and offering amount are measured in millions of dollars. Offer size is computed as the number of shares offered divided by the number of shares outstanding before the offering. 
Table 2. Descriptive statistics

\begin{tabular}{|c|c|c|c|c|c|c|c|}
\hline & Mean & Median & $\begin{array}{c}\text { First } \\
\text { quartile }\end{array}$ & $\begin{array}{c}\text { Third } \\
\text { quartile }\end{array}$ & $\begin{array}{l}\text { Standard } \\
\text { deviation }\end{array}$ & t-values & Prob $>t$ \\
\hline$C M$ & 8.1271 & 8.7500 & 7.5000 & 8.8800 & 1.3537 & 145.83 & 0.0001 \\
\hline$D A_{0}$ & 0.0190 & 0.0154 & -0.0472 & 0.0774 & 0.1848 & 2.68 & 0.0075 \\
\hline$A R_{l}$ & -0.1818 & -0.1848 & -0.4796 & 0.0632 & 0.3992 & -11.25 & 0.0001 \\
\hline NONB6 & 0.0999 & 0.0000 & 0.0000 & 0.0000 & 0.3000 & 8.69 & 0.0001 \\
\hline$R O A_{0}$ & 0.0104 & 0.0545 & 0.0014 & 0.1120 & 0.2299 & 1.10 & 0.2725 \\
\hline$\triangle R O A_{I}$ & -0.0169 & -0.0099 & -0.0579 & 0.0190 & 0.1201 & -3.53 & 0.0004 \\
\hline OCFlow 0 & 0.0213 & 0.0720 & -0.0249 & 0.1466 & 0.2931 & 1.89 & 0.0592 \\
\hline Size & 5.4208 & 5.4014 & 4.4240 & 6.4782 & 1.5833 & 88.29 & 0.0001 \\
\hline Off_Size & 0.2686 & 0.1990 & 0.1190 & 0.3120 & 0.3773 & 18.50 & 0.0001 \\
\hline LEND & 0.8195 & 1.2495 & 0.5456 & 2.2225 & 18.5279 & 1.15 & 0.2506 \\
\hline FEO2 & 0.1909 & 0.0000 & 0.0000 & 0.0000 & 0.3933 & 12.67 & 0.0001 \\
\hline$B M$ & 0.3869 & 0.3378 & 0.1901 & 0.5211 & 0.3715 & 26.86 & 0.0001 \\
\hline
\end{tabular}

This table presents the descriptive statistics of variables used in regression analyses for a full sample of 590 offerings except for $R O A_{0}$. Descriptive statistics of $R O A_{0}$ is calculated based on 587 offerings after eliminating three offerings with extreme $R O A_{0}$. The mean value of $R O A_{0}$ is -0.0087 with insignificant t-value when three offerings with extreme $R O A_{0}$ are included. $C M$ is Carter-Manaster Reputation Ranking. $D A_{0}$ is unexpected accruals summed over $\mathrm{Q}(-1)$ to $\mathrm{Q}(+2)$ and scaled by assets at the beginning of Q(-1), where Q (-1) is the quarter of the last earnings announcement before the offering announcement, $\mathrm{Q}(0)$ is the quarter of the first earnings announcement after the offering announcement, and all other quarters are similarly indexed relative to the offering announcement. $A R_{I}$ is market-adjusted returns compounded daily over the one-year period after the $\mathrm{Q}(+2)$ earnings announcement. NONB6 is an indicator variable of auditor quality and is set to equal 1 for NON-Big-Six auditor, 0 otherwise. $R O A_{0}$ is $\mathrm{Year}(0) R O A$ and it is measured as income before extraordinary items summed over $\mathrm{Q}(-1)$ to $\mathrm{Q}(+2)$ and scaled by assets at the beginning of Q(-1). $\triangle R O A_{1}$ is changes in $R O A$ and it is measured as 'year(1) $R O A-\operatorname{year}(0) R O A$ '. Year(1) $R O A$ is income before extraordinary items summed over $\mathrm{Q}(+3)$ to $\mathrm{Q}(+6)$ and scaled by assets at the beginning of $\mathrm{Q}(+3)$. OCFlow w $_{0}$ is cash flows from operating activities summed over $\mathrm{Q}(-1)$ to $\mathrm{Q}(+2)$ and scaled by assets at the beginning of $\mathrm{Q}(-1)$. Size is $\log$ of market value of equity at the beginning of Q(-1). Off_Size is computed as the number of shares offered divided by the number of shares outstanding before the offering. $L E N D$ is long-term debt over total stockholders' equity. FEO2 is an indicator variable which is set to equal 1 if the firm accesses the capital market to raise additional capital during the two-year period after the seasoned equity offering and 0 otherwise. $B M$ is Book-to-market ratio at the beginning of $\mathrm{Q}(-1)$. 
Table 3. Bivariate correlations among selected variables

\begin{tabular}{|c|c|c|c|c|c|c|c|c|c|c|c|c|}
\hline & $C M$ & $D A_{0}$ & $A R_{I}$ & NONB6 & $R O A_{0}$ & $\triangle R O A_{1}$ & OCFlow $_{0}$ & Size & Off_Size & LEND & FEO2 & $B M$ \\
\hline$C M$ & 1 & $-0.1170^{a}$ & $0.1868^{a}$ & $-0.1638^{a}$ & $0.2666^{a}$ & 0.0027 & $0.3209^{a}$ & $0.4720^{a}$ & $-0.1200^{a}$ & -0.0150 & -0.0490 & 0.0100 \\
\hline$D A_{0}$ & $-0.0983^{b}$ & 1 & $-0.1735^{a}$ & $0.1551^{a}$ & $0.0988^{b}$ & $-0.1612^{a}$ & $-0.2712^{a}$ & $-0.0924^{b}$ & 0.0010 & -0.0289 & -0.0507 & 0.0283 \\
\hline$A R_{I}$ & $0.2037^{a}$ & $-0.1278^{a}$ & 1 & -0.0267 & 0.0802 & $0.2346^{a}$ & $0.1627^{a}$ & $0.1631^{a}$ & -0.0558 & 0.0457 & $0.1838^{a}$ & $0.0996^{b}$ \\
\hline NONB6 & $-0.1233^{a}$ & $0.1588^{a}$ & -0.0403 & 1 & 0.0115 & -0.0101 & -0.0515 & $-0.1898^{a}$ & 0.0188 & 0.0054 & 0.0609 & 0.0153 \\
\hline $\mathrm{ROA}_{0}$ & 0.0093 & $0.2507^{a}$ & 0.0570 & 0.0672 & 1 & $-0.5018^{a}$ & $0.8408^{a}$ & $0.2094^{a}$ & -0.0477 & -0.0051 & -0.0298 & 0.0587 \\
\hline$\triangle R O A_{1}$ & 0.0502 & $-0.2177^{a}$ & $0.3314^{a}$ & -0.0090 & $-0.4554^{a}$ & 1 & $-0.2868^{a}$ & 0.0011 & 0.0565 & 0.0105 & 0.0832 & 0.0170 \\
\hline OCFlow $_{0}$ & $0.1624^{a}$ & $-0.3857^{a}$ & $0.1921^{a}$ & -0.0411 & $0.5271^{a}$ & $-0.1442^{a}$ & 1 & $0.2559^{a}$ & -0.0380 & 0.0061 & 0.0131 & 0.0614 \\
\hline Size & $0.4839^{a}$ & -0.0789 & $0.1948^{a}$ & $-0.1695^{a}$ & $0.1213^{a}$ & 0.0121 & $0.2416^{a}$ & 1 & $-0.3737^{a}$ & -0.0045 & 0.0048 & $-0.1139^{a}$ \\
\hline Off_Size & $-0.2299^{a}$ & 0.0388 & $-0.1339^{a}$ & $0.0916^{b}$ & -0.0680 & 0.0317 & $-0.1235^{a}$ & $-0.6782^{a}$ & 1 & 0.0185 & -0.0331 & $0.0841^{b}$ \\
\hline LEND & $0.1512^{a}$ & -0.0157 & $0.1085^{b}$ & -0.0603 & $-0.1062^{b}$ & 0.0768 & $0.0941^{b}$ & $0.1474^{a}$ & -0.0053 & 1 & 0.0211 & 0.0748 \\
\hline FEO2 & -0.0058 & -0.0712 & $0.1919^{a}$ & 0.0609 & -0.0646 & $0.1398^{a}$ & 0.0385 & -0.0070 & -0.0450 & $0.1116^{a}$ & 1 & 0.0413 \\
\hline$B M$ & 0.0770 & 0.0618 & $0.1141^{a}$ & -0.0241 & $-0.1243^{a}$ & 0.0428 & -0.0178 & $-0.0996^{b}$ & $0.1282^{a}$ & $0.3382^{a}$ & 0.0661 & 1 \\
\hline
\end{tabular}


Table 3. continued.

Upper-triangle presents Pearson correlations and lower-triangle presents Spearman correlations of variables. $C M$ is Carter-Manaster Reputation Ranking. $D A_{0}$ is unexpected accruals summed over $\mathrm{Q}(-1)$ to $\mathrm{Q}(+2)$ and scaled by assets at the beginning of $\mathrm{Q}(-1)$, where $\mathrm{Q}(-1)$ is the quarter of the last earnings announcement before the offering announcement, $\mathrm{Q}(0)$ is the quarter of the first earnings announcement after the offering announcement, and all other quarters are similarly indexed relative to the offering announcement. $A R_{I}$ is market-adjusted returns compounded daily over the one-year period after the $\mathrm{Q}(+2)$ earnings announcement. NONB6 is an indicator variable of auditor quality and is set to equal 1 for NON-Big-Six auditor, 0 otherwise. $R O A_{0}$ is $\mathrm{Year}(0) R O A$ and it is measured as income before extraordinary items summed over $\mathrm{Q}(-1)$ to $\mathrm{Q}(+2)$ and scaled by assets at the beginning of $\mathrm{Q}(-1) . \triangle R O A_{1}$ is changes in $R O A$ and it is measured as 'year(1) $R O A-\operatorname{year}(0) R O A$ '. Year(1) $R O A$ is income before extraordinary items summed over $\mathrm{Q}(+3)$ to $\mathrm{Q}(+6)$ and scaled by assets at the beginning of $\mathrm{Q}(+3)$. OCFlow ${ }_{0}$ is cash flows from operating activities summed over $\mathrm{Q}(-1)$ to $\mathrm{Q}(+2)$ and scaled by assets at the beginning of Q(-1). Size is $\log$ of market value of equity at the beginning of Q(-1). Off_Size is computed as the number of shares offered divided by the number of shares outstanding before the offering. LEND is long-term debt over total stockholders' equity. FEO2 is an indicator variable which is set to equal 1 if the firm accesses the capital market to raise additional capital during the two-year period after the seasoned equity offering and 0 otherwise. $B M$ is Book-to-market ratio at the beginning of Q(-1).

${ }^{a}$ Significant at the $1 \%$ level based on a two-sided test. ${ }^{b}$ Significant at the $5 \%$ level based on a two-sided test. 
Table 4. Underwriter reputation, earnings management, and post-issue performance of SEOs

Panel A: Underwriter ranking, unexpected accruals, and post-issue returns for 30 individual underwriters

\begin{tabular}{|c|c|c|c|c|c|c|}
\hline & \multirow{2}{*}{$\begin{array}{c}\text { \# of } \\
\text { SEOs }\end{array}$} & \multirow[b]{2}{*}{$C M$} & \multicolumn{2}{|c|}{$D A_{0}$} & \multicolumn{2}{|c|}{$A R_{I}$} \\
\hline & & & Mean & Median & Mean & Median \\
\hline Goldman, Sachs \& Company & 45 & 9 & 0.0042 & 0.0029 & -0.0991 & -0.0718 \\
\hline Salomon Brothers & 31 & 9 & -0.0023 & -0.0218 & -0.1144 & -0.1335 \\
\hline First Boston Corp. & 30 & 9 & -0.0081 & 0.0163 & -0.1180 & -0.0232 \\
\hline Hambrecht \& Quist & 21 & 9 & -0.0515 & 0.0145 & -0.0208 & -0.0947 \\
\hline Merrill Lynch White Weld Cap. & 57 & 8.88 & 0.0057 & 0.0048 & -0.0859 & -0.0731 \\
\hline Morgan Stanley \& Company & 42 & 8.88 & 0.0114 & 0.0173 & -0.0976 & -0.1048 \\
\hline Brown, Alex \& Sons & 22 & 8.88 & -0.0203 & -0.0172 & -0.1365 & -0.2287 \\
\hline Kidder, Peabody, \& Company & 10 & 8.83 & 0.0547 & 0.0358 & -0.3990 & -0.3883 \\
\hline Shearson Lehmann & 2 & 8.83 & -0.0419 & -0.0419 & -0.1950 & -0.1950 \\
\hline Wertheim \& Company & 1 & 8.83 & -0.0655 & -0.0655 & N/A & N/A \\
\hline High-Reputation Group Total & 261 & & -0.0017 & 0.0063 & -0.1106 & -0.0878 \\
\hline (p-value) & & & $(0.8436)$ & $(0.4875)$ & $(0.0001)$ & $(0.0001)$ \\
\hline Dillon Read & 12 & 8.63 & -0.0509 & -0.0773 & -0.0168 & 0.0107 \\
\hline Dean Witter Reynolds & 1 & 8.5 & 0.2208 & 0.2208 & -0.7283 & -0.7283 \\
\hline Edwards, A. G. \& Sons & 4 & 8 & 0.0455 & 0.0333 & -0.0239 & 0.0101 \\
\hline Blair, D. H. \& Company & 1 & 8 & -0.0821 & -0.0821 & -0.9549 & -0.9549 \\
\hline Oppenheimer \& Company & 11 & 7.88 & -0.0373 & 0.0289 & -0.2695 & -0.3746 \\
\hline Blair, William \& Company & 9 & 7.88 & 0.1228 & 0.1398 & -0.3362 & -0.2921 \\
\hline Piper, Jaffray \& Hopwood & 2 & 7.75 & -0.0307 & -0.0307 & -0.5301 & -0.5301 \\
\hline Dain Bosworth & 5 & 7.63 & 0.1543 & 0.1283 & -0.3255 & -0.4068 \\
\hline Lehman Brothers, Kuhn Loeb, Inc. & 40 & 7.5 & -0.0017 & 0.0135 & -0.1844 & -0.1146 \\
\hline Robinson-Humphrey Company & 6 & 7.38 & 0.0846 & 0.0501 & -0.3674 & -0.3542 \\
\hline Median-Reputation Group Total & 91 & & 0.0177 & 0.0161 & -0.2242 & -0.2312 \\
\hline (p-value) & & & $(0.2444)$ & $(0.1600)$ & $(0.0001)$ & $(0.0001)$ \\
\hline Paulson Investment Company & 5 & 5 & 0.1981 & 0.0924 & -0.5390 & -0.6422 \\
\hline Brean Murray, Foster & 1 & 5 & -0.0764 & -0.0764 & -0.8872 & -0.8872 \\
\hline Parker/Hunter & 1 & 4.88 & 0.1968 & 0.1968 & 0.4394 & 0.4394 \\
\hline Reich \& Company & 1 & 4 & 0.1974 & 0.1974 & -0.5782 & -0.5782 \\
\hline Wedbush, Noble, Cooke & 1 & 4 & 0.3809 & 0.3809 & -0.7562 & -0.7562 \\
\hline Van Kasper\& Company & 3 & 3.5 & 0.0820 & -0.0099 & -0.4240 & -0.4240 \\
\hline Whale Securities Corp. & 3 & 3.33 & 0.2421 & 0.1622 & -0.5519 & -0.6042 \\
\hline Donald, N. \& Company Sec. & 1 & 3 & -0.2314 & -0.2314 & 0.6060 & 0.6060 \\
\hline Keane Securities & 1 & 3 & 0.0190 & 0.0190 & -0.3474 & -0.3474 \\
\hline Steichen, R. J. \& Company & 2 & 1 & 0.0066 & 0.0066 & -0.2042 & -0.2042 \\
\hline Low-Reputation Group Total & 19 & & 0.1296 & 0.0657 & -0.3877 & -0.5709 \\
\hline (p-value) & & & $(0.0365)$ & $(0.0494)$ & $(0.0026)$ & $(0.0067)$ \\
\hline t-value ${ }_{H-L}$ & & & $-3.68 * * *$ & & $2.79 * * *$ & \\
\hline
\end{tabular}


Table 4. continued.

Panel B: Relationship between underwriter reputation, earnings management, and post-issue performance for full sample

\begin{tabular}{|c|c|c|c|c|c|c|c|}
\hline \multicolumn{2}{|c|}{ Underwriter reputation groups } & \multicolumn{3}{|c|}{$D A_{0}$} & \multicolumn{3}{|c|}{$A R_{1}$} \\
\hline & & Obs. & Mean (p-value) & Median (p-value) & Obs. & Mean (p-value) & Median (p-value) \\
\hline Lowest & $C M=<1 \mathrm{Q}$ & 150 & $0.0331(0.0090)$ & $0.0164(0.0162)$ & 132 & $-0.2896(0.0001)$ & $-0.3132(0.0001)$ \\
\hline 2 & $1 \mathrm{Q}<C M=<$ Median & 179 & $0.0112(0.3498)$ & $0.0158(0.0512)$ & 165 & $-0.1834(0.0001)$ & $-0.1982(0.0001)$ \\
\hline 3 & Median $<C M=<3 \mathrm{Q}$ & 134 & $0.0057(0.6592)$ & $0.0142(0.1119)$ & 118 & $-0.1274(0.0003)$ & $-0.1263(0.0002)$ \\
\hline Highest & $C M>3 \mathrm{Q}$ & 127 & $-0.0095(0.4219)$ & $0.0029(0.5432)$ & 119 & $-0.0941(0.0136)$ & $-0.0752(0.0101)$ \\
\hline Total & & 590 & & & 534 & & \\
\hline $\mathrm{t}$-value ${ }_{H-t}$ & & & $-2.48 * *$ & & & $3.91 * * *$ & \\
\hline
\end{tabular}

These tables present the descriptive statistics of unexpected accruals and one-year post-issue returns for 30 individual underwriters in Panel A and the various underwriter reputation groups in Panel B. $C M$ is Carter-Manaster Reputation Ranking. $D A_{0}$ is unexpected accruals summed over $\mathrm{Q}(-1)$ to $\mathrm{Q}(+2)$ and scaled by assets at the beginning of $\mathrm{Q}(-1)$, where the quarter of the last earnings announcement before the offering announcement is labeled $Q(-1)$ and $Q(+2)$ is the second quarter of the first earnings announcement after the offering announcement. $A R_{l}$ is market-adjusted returns compounded daily over the one-year period after the $\mathrm{Q}(+2)$ earnings announcement. 
Table 5. Simultaneous association between underwriter reputation and earnings management

\begin{tabular}{|c|c|c|c|c|c|c|}
\hline \multirow[b]{2}{*}{$\begin{array}{l}\text { Independent } \\
\text { variables }\end{array}$} & \multicolumn{2}{|c|}{ Model 1} & \multicolumn{2}{|c|}{ Model 2} & \multicolumn{2}{|c|}{ Model 3} \\
\hline & $\begin{array}{l}\text { Dependent variable: } \\
\qquad M\end{array}$ & $\begin{array}{c}\text { Dependent variable: } \\
\qquad D A_{0}\end{array}$ & $\begin{array}{c}\text { Dependent variable: } \\
C M\end{array}$ & $\begin{array}{c}\text { Dependent variable: } \\
\qquad A_{0}\end{array}$ & $\begin{array}{c}\text { Dependent variable: } \\
C M\end{array}$ & $\begin{array}{c}\text { Dependent variable: } \\
\qquad D A_{0}\end{array}$ \\
\hline$D A_{0}$ & $\begin{array}{r}-2.0775 \\
(-5.61) * * *\end{array}$ & & $\begin{array}{r}-2.0449 \\
(-5.10)\end{array} * * *$ & & $\begin{array}{r}-2.3122 \\
(-5.80)\end{array} * * *$ & \\
\hline$C M$ & & $\begin{array}{r}-0.6587 \\
(-6.79)\end{array} * * *$ & & $\begin{array}{l}-0.0680 \\
(-2.93)\end{array} * * *$ & & $\begin{array}{r}-0.0771 \\
(-3.31)\end{array} * * *$ \\
\hline NONB6 & $\begin{array}{r}-0.1116 \\
(-0.49)\end{array}$ & $\begin{array}{r}-0.0967 \\
(-0.86)\end{array}$ & $\begin{array}{r}-0.1423 \\
(-0.62)\end{array}$ & $\begin{array}{c}0.0864 \\
(1.78)\end{array}$ & & $\begin{array}{l}0.0939 \\
(2.19) * *\end{array}$ \\
\hline$R O A_{0}$ & $\begin{array}{c}0.4192 \\
(1.72)\end{array}$ & & $\begin{array}{r}0.5731 \\
(2.28)\end{array} * *$ & & $\begin{array}{c}0.6010 \\
(2.38)\end{array} * *$ & \\
\hline OCFlow $_{0}$ & & $\begin{array}{r}0.2586 \\
(1.94)\end{array}$ & & $\begin{array}{l}-0.2102 \\
(-3.30)\end{array} * * *$ & & $\begin{array}{r}-0.1892 \\
(-3.05)\end{array} * * *$ \\
\hline$\triangle R O A_{1}$ & & $\begin{array}{c}-0.1332 \\
(-2.01)\end{array} * *$ & & $\begin{array}{l}-0.5101 \\
(-10.60)\end{array} * * *$ & & $\begin{array}{l}-0.4874 \\
(-10.24) * * *\end{array}$ \\
\hline Size & $\begin{array}{l}0.3399 \\
(8.04) * * *\end{array}$ & $\begin{array}{l}0.2303 \\
(5.76)\end{array} * * *$ & $\begin{array}{l}0.3261 \\
(7.37) * * *\end{array}$ & & 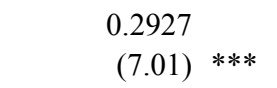 & \\
\hline Off_Size & $\begin{array}{r}-0.0950 \\
(-1.23)\end{array}$ & & $\begin{array}{r}0.2156 \\
(1.55)\end{array}$ & & & \\
\hline LEND & & $\begin{array}{r}-0.0004 \\
(-1.03)\end{array}$ & & $\begin{array}{r}-0.0001 \\
(-0.09)\end{array}$ & & \\
\hline$R \& D$ & $\begin{array}{c}0.0328 \\
(1.92)\end{array}$ & $\begin{array}{r}0.0211 \\
(2.44)\end{array} * *$ & $\begin{array}{r}0.0346 \\
(2.02)\end{array} * *$ & $\begin{array}{r}0.0006 \\
(0.16)\end{array}$ & $\begin{array}{c}0.0322 \\
(2.13) * *\end{array}$ & \\
\hline Tobin's $q$ & $\begin{array}{r}-0.0672 \\
(-2.00)\end{array} * *$ & $\begin{array}{r}-0.0429 \\
(-2.51)\end{array} * *$ & $\begin{array}{c}-0.0564 \\
(-1.68)\end{array}$ & $\begin{array}{r}-0.0016 \\
(-0.24)\end{array}$ & $\begin{array}{c}-0.0523 \\
(-1.76)\end{array}$ & \\
\hline Industry dummies & Yes & Yes & Yes & Yes & Yes & Yes \\
\hline Number of observa & ations & & & & & 7 \\
\hline System weighted $R$ & & $51 \%$ & & & & $97 \%$ \\
\hline
\end{tabular}


Table 5. continued.

This table reports results of association between underwriter reputation and earnings management in the systems of the three stage least square equations. $C M$ is Carter-Manaster Reputation Ranking. $D A_{0}$ is unexpected accruals summed over $\mathrm{Q}(-1)$ to $\mathrm{Q}(+2)$ and scaled by assets at the beginning of $\mathrm{Q}(-1)$. NONB6 is an indicator variable of auditor quality and is set to equal 1 for NON-Big-Six auditor, 0 otherwise. $R O A_{0}$ is $\mathrm{Year}(0) R O A$ and it is measured as income before extraordinary items summed over $\mathrm{Q}(-1)$ to $\mathrm{Q}(+2)$ and scaled by assets at the beginning of $\mathrm{Q}(-1)$. OCFlow $w_{0}$ is cash flows from operating activities summed over $\mathrm{Q}(-1)$ to $\mathrm{Q}(+2)$ and scaled by assets at the beginning of $\mathrm{Q}(-1)$. $\triangle R O A_{1}$ is changes in $R O A$ and it is measured as 'year(1) $R O A$ - year(0) $R O A$ '. Year(1) $R O A$ is income before extraordinary items summed over $\mathrm{Q}(+3)$ to $\mathrm{Q}(+6)$ and scaled by assets at the beginning of $\mathrm{Q}(+3)$. Size is $\log$ of market value of equity at the beginning of Q(-1). Off_Size is computed as the number of shares offered divided by the number of shares outstanding before the offering. $L E N D$ is long-term debt over total stockholders' equity. $R \& D$ is R\&D intensity in the last fiscal year ending before SEO announcement and calculated as the ratio of the annual R\&D expenditures to total sales. Tobin's $q$ is Chung and Pruitt (1994) measure of Tobins' q and calculated as $\{[$ Market value of common stock + Book value of preferred stock + Book value of long-term debt + Book value of current liabilities - (Book value of current assets - Book value of Inventories)] / Book value of total assets $\}$ in the last fiscal year ending before SEO announcement. *** (**) Significant at the 1\% (5\%) level based on a two-sided test. 
Table 6. Simultaneous association between underwriter reputation and earnings management - Alternative earnings management proxies

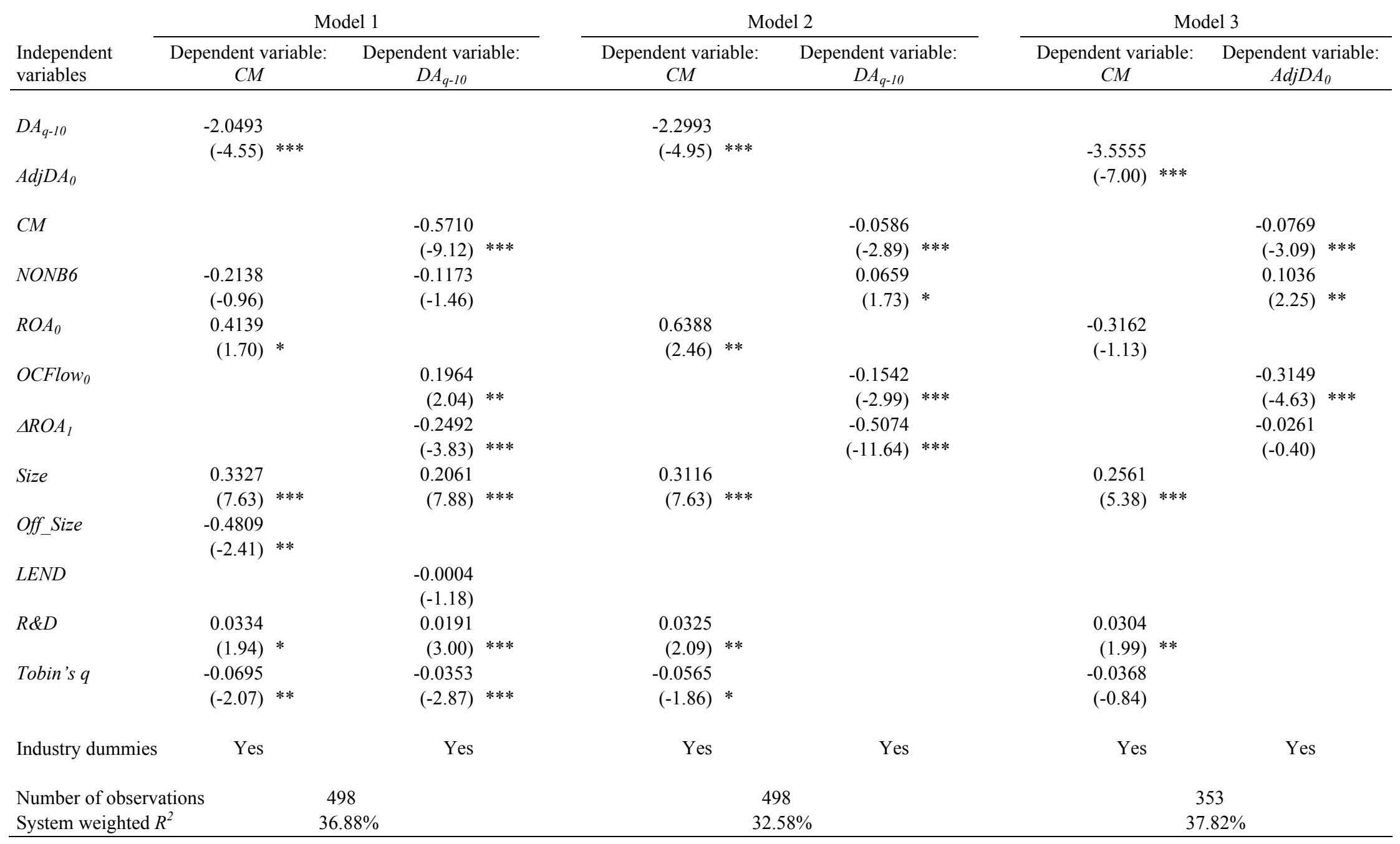


Table 6. continued.

This table reports results of association between underwriter reputation and earnings management, conditional on disclosure frequency changes immediately preceding the SEO announcement. The systems of the three stage least square equations are estimated separately for the sample SEOs whose issuers increase disclosure frequency during the sixmonth period immediately preceding the offering announcement, and for the sample SEOs whose issuers do not increase disclosure frequency. CM is Carter-Manaster Reputation Ranking. $D A_{q-10}$ is unexpected accruals summed over $\mathrm{Q}(-1)$ and $\mathrm{Q}(0)$ and scaled by assets at the beginning of $\mathrm{Q}(-1)$. AdjDA $A_{0}$ is unexpected accruals of SEO firm minus the unexpected accruals of the performance matched, non-SEO firm, summed over $\mathrm{Q}(-1)$ to $\mathrm{Q}(+2)$ and scaled by assets at the beginning of $\mathrm{Q}(-1)$. NONB6 is an indicator variable of auditor quality and is set to equal 1 for NON-Big-Six auditor, 0 otherwise. $R O A_{0}$ is $\mathrm{Year}(0) R O A$ and it is measured as income before extraordinary items summed over Q(-1) to $\mathrm{Q}(+2)$ and scaled by assets at the beginning of $\mathrm{Q}(-1)$. OCFlow $w_{0}$ is cash flows from operating activities summed over $\mathrm{Q}(-1)$ to $\mathrm{Q}(+2)$ and scaled by assets at the beginning of $\mathrm{Q}(-1)$. $\triangle R O A_{l}$ is changes in $R O A$ and it is measured as 'year(1) $R O A-$ year(0) $R O A$ '. Year(1) $R O A$ is income before extraordinary items summed over $\mathrm{Q}(+3)$ to $\mathrm{Q}(+6)$ and scaled by assets at the beginning of $\mathrm{Q}(+3)$. Size is log of market value of equity at the beginning of Q(-1). Off_Size is computed as the number of shares offered divided by the number of shares outstanding before the offering. $L E N D$ is long-term debt over total stockholders' equity. $R \& D$ is R\&D intensity in the last fiscal year ending before SEO announcement and calculated as the ratio of the annual R\&D expenditures to total sales. Tobin's $q$ is Chung and Pruitt (1994) measure of Tobins' q and calculated as $\{[$ Market value of common stock + Book value of preferred stock + Book value of long-term debt + Book value of current liabilities - (Book value of current assets - Book value of Inventories)] / Book value of total assets $\}$ in the last fiscal year ending before SEO announcement. *** (**) Significant at the 1\% (5\%) level based on a two-sided test. 
Table 7. Out-of-sample test of the association between underwriter reputation and incidence of AAERs

Panel A: Number of offerings subject to AAERs

Initial search of AAERs (by 12/31/2004) with a keyword "offering" 335

less: debt offerings, private placement, offerings not related to AAERs

$\frac{88}{247}$

less: duplicate AAERs

$\frac{103}{144}$

less: AAERs related to offerings prior to 1988 and after 1997

$\frac{68}{76}$

less: not matched with SDC data (includes offerings only considered,

withdrawn, etc.)

less: Carter-Manaster ranking is not available

$\frac{18}{58}$

AAERs used in analyses

26

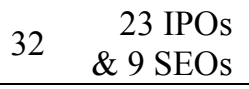

Panel B: Number of public equity offerings during 1988-1997

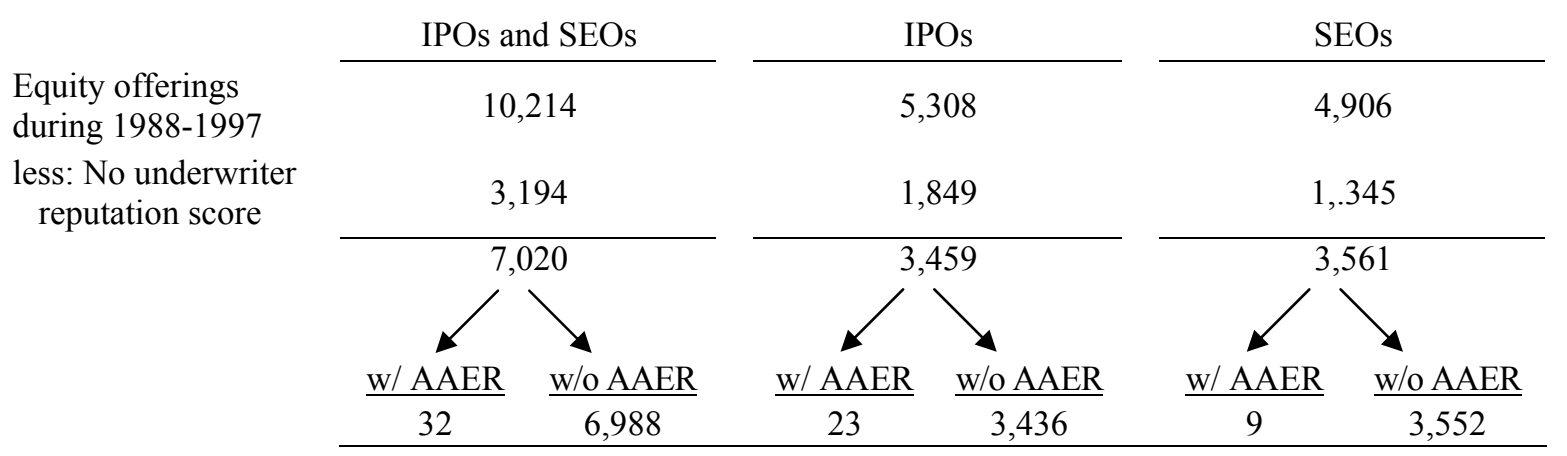

Panel C: Underwriter reputation scores of equity offerings with and without AAERs

\begin{tabular}{|c|c|c|c|c|c|c|}
\hline & \multicolumn{2}{|c|}{ IPOs and SEOs } & \multicolumn{2}{|c|}{ IPOs } & \multicolumn{2}{|c|}{ SEOs } \\
\hline & $\underline{\mathrm{w} / \mathrm{AAER}}$ & w/o AAER & $\underline{\mathrm{w} / \mathrm{AAER}}$ & w/o AAER & $\underline{\mathrm{w} / \mathrm{AAER}}$ & w/o AAER \\
\hline Number of observations & 32 & 6988 & 23 & 3436 & 9 & 3552 \\
\hline Mean & 7.41 & 8.01 & 7.40 & 7.87 & 7.43 & 8.14 \\
\hline Standard deviation & 2.15 & 1.57 & 2.31 & 1.75 & 1.80 & 1.36 \\
\hline Minimum & 1 & 0 & 1 & 0 & 4.5 & 0 \\
\hline Maximum & 9 & 9 & 9 & 9 & 8.88 & 9 \\
\hline \multicolumn{7}{|l|}{ Difference tests } \\
\hline t-test p-value & \multicolumn{2}{|c|}{0.0157} & \multicolumn{2}{|c|}{0.0994} & \multicolumn{2}{|c|}{0.0598} \\
\hline Wilcoxon test $p$-value & \multicolumn{2}{|c|}{0.0312} & \multicolumn{2}{|c|}{0.1189} & \multicolumn{2}{|c|}{0.0902} \\
\hline
\end{tabular}


Table 7. continued.

Panel A and B of this table present the sampling process and Panel C presents the results from the out-of-sample tests examining the association between underwriter reputation and the incidence of AAERs (Accounting and Auditing Enforcement Release) through the Lexis Nexis search. We expand the analysis to include all equity offerings, both IPOs and SEOs, during the ten-year period between 1988 and 1997. 
Table 8. Regression of post-issue market-adjusted returns on underwriter reputation

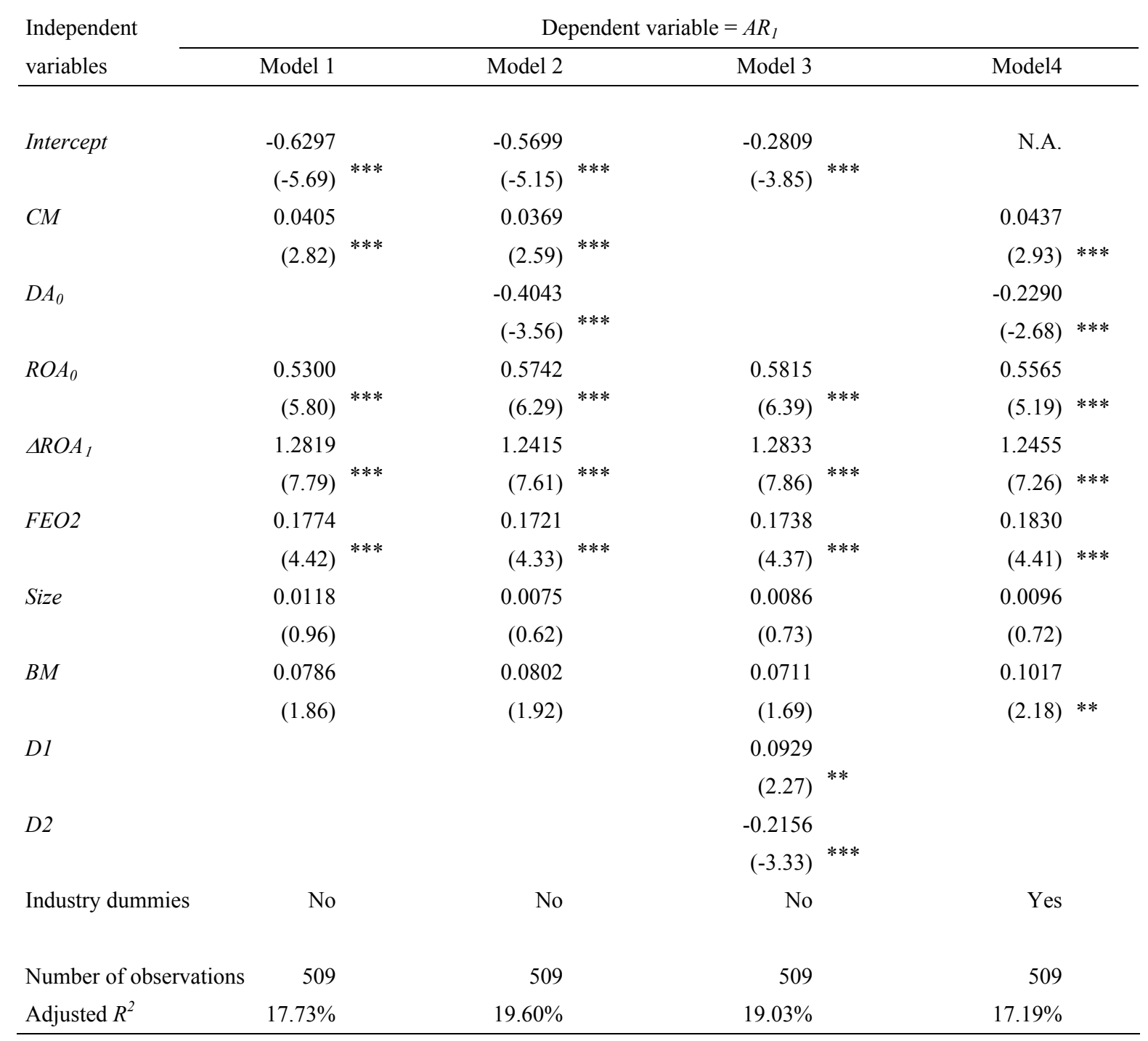


Table 8. continued.

This table presents regression results of post-issue market adjusted buy-and-hold returns on underwriter reputation, earnings management and other control variables. $A R_{l}$ is market-adjusted returns compounded daily over the one-year period after the $\mathrm{Q}(+2)$ earnings announcement, where $\mathrm{Q}(+2)$ is the second quarter of the first earnings announcement after the offering announcement. $C M$ is Carter-Manaster Reputation Ranking. $D A_{0}$ is unexpected accruals summed over $\mathrm{Q}(-1)$ to $\mathrm{Q}(+2)$ and scaled by assets at the beginning of $\mathrm{Q}(-1)$, where $\mathrm{Q}(-1)$ is the quarter of the last earnings announcement before the offering announcement, $\mathrm{Q}(0)$ is the quarter of the first earnings announcement after the offering announcement, and all other quarters are similarly indexed relative to the offering announcement. $R O A_{0}$ is $\operatorname{Year}(0) R O A$ and it is measured as income before extraordinary items summed over $\mathrm{Q}(-1)$ to $\mathrm{Q}(+2)$ and scaled by assets at the beginning of $\mathrm{Q}(-1) . \triangle R O A_{1}$ is changes in $R O A$ and it is measured as 'year(1) $R O A$ - year(0) $R O A$ '. Year(1) $R O A$ is income before extraordinary items summed over $\mathrm{Q}(+3)$ to $\mathrm{Q}(+6)$ and scaled by assets at the beginning of $\mathrm{Q}(+3)$. FEO2 is an indicator variable which is set to equal 1 if the firm accesses the capital market to raise additional capital during the two-year period after the seasoned equity offering and 0 otherwise. Size is log of market value of equity at the beginning of $\mathrm{Q}(-1) . B M$ is Book-to-market ratio at the beginning of $\mathrm{Q}(-1)$. If $C M>=$ third quartile $(C M)$ and $D A_{0}$ $<$ first quartile $\left(D A_{0}\right)$ then $D 1=1$, otherwise $D 1=0$. If $C M<$ first quartile $(C M)$ and $D A_{0}>=$ third quartile $\left(D A_{0}\right)$ then $D 2=1$, otherwise $D 2=0 . * * *(* *)$ Significant at the $1 \%(5 \%)$ level based on a two-sided test. 
Table 9. Regression of post-issue operating performance on underwriter reputation

\begin{tabular}{|c|c|c|c|c|}
\hline \multirow{2}{*}{$\begin{array}{l}\text { Independent } \\
\text { variables }\end{array}$} & \multicolumn{4}{|c|}{ Dependent variable $=\triangle R O A_{1}$} \\
\hline & Model 1 & Model 2 & Model 3 & \\
\hline \multirow[t]{2}{*}{ Intercept } & -0.0131 & -0.1431 & -0.1283 & \\
\hline & $(-1.98)^{* *}$ & $(-3.39)^{* * *}$ & $(-3.05)$ & $* * *$ \\
\hline \multirow[t]{2}{*}{$C M$} & & 0.0155 & 0.0140 & \\
\hline & & $(3.07)^{* * *}$ & $(2.77)$ & $* * *$ \\
\hline \multirow[t]{2}{*}{$D A_{0}$} & -0.1447 & & -0.1310 & \\
\hline & $(-3.15)^{* * *}$ & & $(-2.86)$ & $* * *$ \\
\hline \multirow[t]{2}{*}{ SGROA } & 0.0054 & 0.0049 & 0.0047 & \\
\hline & $(0.67)$ & $(0.61)$ & $(0.59)$ & \\
\hline \multirow[t]{2}{*}{ CAPGROA } & -0.0470 & -0.0410 & -0.0434 & \\
\hline & $(-2.10)^{* *}$ & $(-1.83)^{*}$ & $(-1.95)$ & $* *$ \\
\hline Number of observations & 467 & 467 & 467 & \\
\hline Adjusted $R^{2}$ & $2.34 \%$ & $2.23 \%$ & $3.72 \%$ & \\
\hline
\end{tabular}

This table presents regression results of post-issue operating performance on underwriter reputation, earnings management and other control variables. This table follows Rangan (1998)'s specification for the test. $\triangle R O A_{1}$ is changes in $R O A$ and it is measured as 'year(1) $R O A$ - year(0) $R O A$ '. Year(1) $R O A$ is income before extraordinary items summed over $\mathrm{Q}(+3)$ to $\mathrm{Q}(+6)$ and scaled by assets at the beginning of $\mathrm{Q}(+3)$. Year $(0) R O A$ is income before extraordinary items summed over $\mathrm{Q}(-1)$ to $\mathrm{Q}(+2)$ and scaled by assets at the beginning of $\mathrm{Q}(-1) . D A_{0}$ is unexpected accruals summed over $\mathrm{Q}(-1)$ to $\mathrm{Q}(+2)$ and scaled by assets at the beginning of $\mathrm{Q}(-1)$, where $\mathrm{Q}(-1)$ is the quarter of the last earnings announcement before the offering announcement, $\mathrm{Q}(0)$ is the quarter of the first earnings announcement after the offering announcement, and all other quarters are similarly indexed relative to the offering announcement. $C M$ is Carter-Manaster Reputation Ranking. SGROA is the percentage growth rate in sales from year(-1) to year(0). Sales for year(0) is net sales summed over $Q(-1)$ to $Q(+2)$ and sales for year(-1) is net sales summed over $Q(-$ 5) to $\mathrm{Q}(-2)$. CAPGROA is the percentage growth rate in capital expenditures from year(-1) to year(0). *** (**) Significant at the $1 \%(5 \%)$ level based on a two-sided test. 
Table 10. Long-term post-issue return performance and difference tests

Panel A: post-issue returns

$\frac{\text { Group } 1 \text { (High CM, High EM) }}{\text { Mean }}$

$\frac{\text { Group } 2(\text { High CM , Low EM) }}{\text { Mean }}$

\begin{tabular}{cc} 
Group $3($ Low CM, High EM) \\
\hline Mean
\end{tabular}

\begin{tabular}{lc} 
Group 4 (Low CM, Low EM) \\
\hline Mean
\end{tabular}

1 year Buy-and-hold returns

$$
\begin{array}{lllll}
-0.14534 * * * & -0.11456 & * * * & -0.03053 & -0.02091
\end{array}
$$

Monthly abnormal returns from Fama French three-factor model estimated over 12 months

$$
\begin{array}{llll}
-0.00460 & -0.00726 & -0.00100 & -0.00042
\end{array}
$$

Monthly abnormal returns from Fama French three-factor model estimated over 24 months

$$
\begin{array}{llll}
-0.00456 & -0.00589 & -0.00282 & -0.00165
\end{array}
$$

Monthly abnormal returns from Fama French three-factor model estimated over 36 months
$-0.00562$
** $\quad-0.00458 \quad * *$
$-0.00178$
$-0.00157$

$-0.20736$

$* * *$

$-0.19823$

$-0.01056$

$* * *$

$-0.00730$

$* * *$

$* * *$

$-0.00834$

$-0.00619$

$-0.00572 * * *$

$-0.00602$

$-0.00654 * * *$

Monthly abnormal returns from Fama French three-factor model estimated over 48 months
$-0.00450$
$-0.00535$
0.00193
0.00008

$-0.00168$

$-0.00170$

Monthly abnormal returns from Fama French three-factor model estimated over 60 months

$\begin{array}{llll}-0.00293 & -0.00177 & 0.00152 & -0.00174\end{array}$

$-0.00040$

0.00145

$-0.00078$

$-0.00107$ 
Table 10. continued.

Panel B: P-values from the One-tailed t-tests and Wilcoxon tests of post-issue returns between groups

1 year Buy-and-hold returns

Monthly abnormal returns from Fama French three-factor model estimated over 12 months Monthly abnormal returns from Fama French three-factor model estimated over 24 months Monthly abnormal returns from Fama French three-factor model estimated over 36 months Monthly abnormal returns from Fama French three-factor model estimated over 48 months Monthly abnormal returns from Fama French three-factor model estimated over 60 months

\begin{tabular}{ccc} 
Group 2 vs. Group 3 & & Group 2 vs. Group 4 \\
\cline { 1 - 1 } $0.0001(0.0001)$ & & $0.0005(0.0004)$ \\
$0.0193(0.0337)$ & & $0.0398(0.0390)$ \\
$0.1564(0.0977)$ & & $0.1621(0.1696)$ \\
$0.2027(0.1797)$ & & $0.3094(0.2527)$ \\
$0.1043(0.1441)$ & & $0.2089(0.2270)$ \\
$0.2699(0.3469)$ & $0.2337(0.3878)$
\end{tabular}

Group 1 vs. Group 3 $0.1021(0.0942)$ $0.0996(0.1326)$ $0.3319(0.3505)$ $0.3533(0.4153)$ $0.2219(0.1758)$ $0.2028(0.0757)$

Panel A presents the post-issue returns up to five years after $Q(+2)$ earnings announcement, where $Q(+2)$ is the second quarter of the first earnings announcement after the offering announcement. Buy-and-hold returns are market-adjusted returns compounded daily over the one-year period after the $\mathrm{Q}(+2)$ earnings announcement. Three-factor model $\alpha$ coefficients are alphas from the Fama-French thee-factor model estimated over 12 month to 60 month periods after the $Q(+2)$ earnings announcement. The following regression is estimated for each firm: $\left(R_{i t}-R_{f t}\right)=\alpha+b_{1}\left(R_{m t}-R_{f t}\right)+b_{2} S M B_{t}+b_{3} H M L_{t}+e_{i t}$ where $R_{i t}$ is monthly return of SEO firm in 12 to 60 month periods after the Q $(+2)$ earnings announcement. If $C M$ is greater than or equal to the median value and $D A_{0}$ is greater than or equal to the median value, then the sample is classified into group 1 . If $C M$ is greater than or equal to the median value and $D A_{0}$ is less than the median value, then the sample is classified into group 2 . If $C M$ is less than the median value and $D A_{0}$ is greater than or equal to the median value, then the sample is classified into group 3. If $C M$ is less than the median value and $D A_{0}$ is less than the median value, then the sample is classified into group 4. *** (**) Significant at the $1 \%(5 \%)$ level based on a one-sided test.

Panel B shows the p-values for the one-tailed t-test (p-values for the one-tailed Wilcoxon test in the parentheses) of post-issue returns between groups. 
Figure 1. Time line of seasoned equity offerings

This figure shows our timing convention. Q(.) represents the quarters around a SEO. The quarter of the last earnings announcement before the offering announcement is labeled $\mathrm{Q}(-1)$. Q(0) is the quarter of the first earnings announcement after the offering announcement. All other quarters are similarly indexed relative to the offering announcement. Eann stands for earnings announcement. SEOann represents SEO announcement. We measure post-issue returns by compounding daily market-adjusted returns over the one-year period after the $\mathrm{Q}(+2)$ earnings announcement. The figure also illustrates important event dates and periods around SEO. 1933 Securities Act prohibits any "offer to sell" prior to the filing of the registration statement before the file of the offer. It also prohibits any sales prior to the effective date. The period between the date of file and the effective date is

"Waiting Period". The average Waiting Period in Rangan (1998) is 35 days. In our sample the average Waiting Period is 49 days and the median is 35 days. Lock-up agreements between issuing firms and their underwriters prevent insiders at issuing firms from selling their holdings until 90 to 180 days after the offering date.

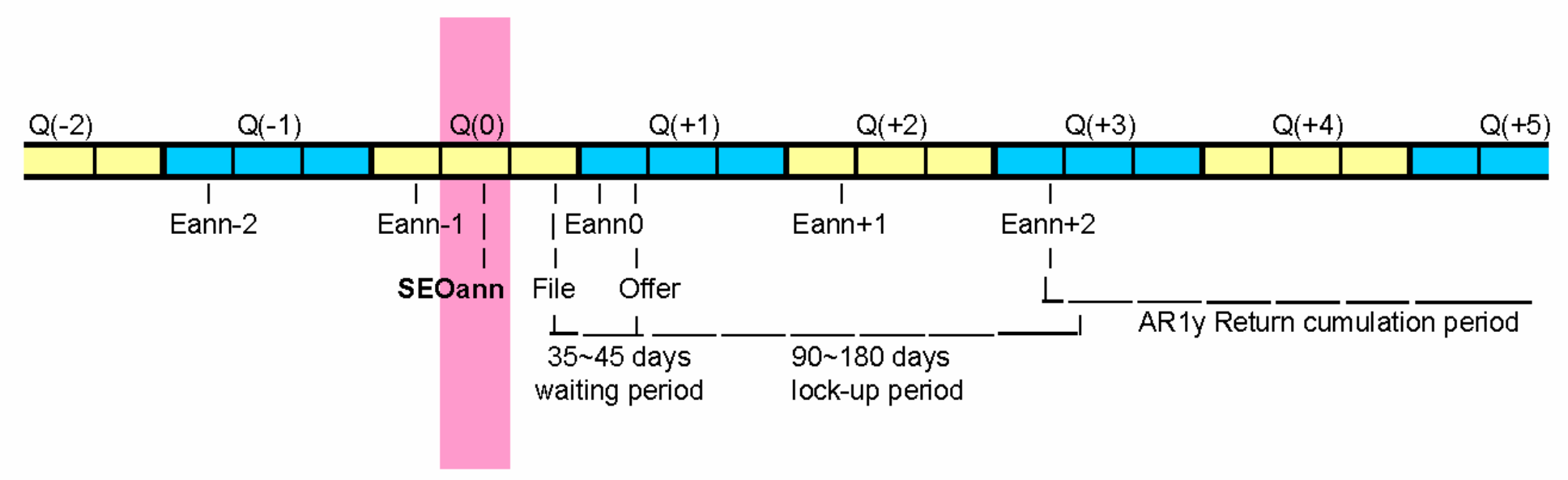

